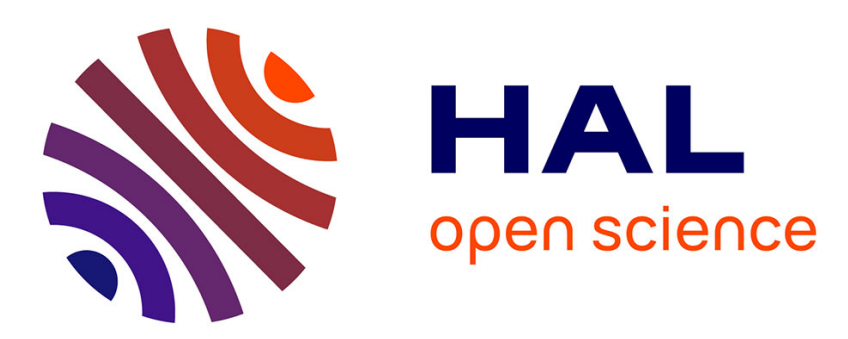

\title{
PATTERNS OF INTENTION: OBERKAMPF AND KNOLL AS SCHUMPETERIAN ENTREPRENEURS
}

Elen Riot

\section{To cite this version:}

Elen Riot. PATTERNS OF INTENTION: OBERKAMPF AND KNOLL AS SCHUMPETERIAN ENTREPRENEURS. Entrepreneurship and Regional Development, 2019, 623-651, 10.1080/08985626.2019.1596359 . hal-02883082

\section{HAL Id: hal-02883082 \\ https://hal.science/hal-02883082}

Submitted on 5 Jul 2020

HAL is a multi-disciplinary open access archive for the deposit and dissemination of scientific research documents, whether they are published or not. The documents may come from teaching and research institutions in France or abroad, or from public or private research centers.
L'archive ouverte pluridisciplinaire HAL, est destinée au dépôt et à la diffusion de documents scientifiques de niveau recherche, publiés ou non, émanant des établissements d'enseignement et de recherche français ou étrangers, des laboratoires publics ou privés. 


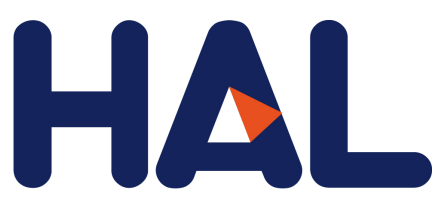

archives-ouvertes

\section{PATTERNS OF INTENTION: OBERKAMPF AND KNOLL AS SCHUMPETERIAN ENTREPRENEURS}

Elen Riot

\section{To cite this version:}

Elen Riot. PATTERNS OF INTENTION: OBERKAMPF AND KNOLL AS SCHUMPETERIAN ENTREPRENEURS. Entrepreneurship and Regional Development, Taylor \& Francis (Routledge), $2019,10.1080 / 08985626.2019 .1596359$. hal-02883082

\section{HAL Id: hal-02883082 \\ https://hal.archives-ouvertes.fr/hal-02883082}

Submitted on 5 Jul 2020

HAL is a multi-disciplinary open access archive for the deposit and dissemination of scientific research documents, whether they are published or not. The documents may come from teaching and research institutions in France or abroad, or from public or private research centers.
L'archive ouverte pluridisciplinaire HAL, est destinée au dépôt et à la diffusion de documents scientifiques de niveau recherche, publiés ou non, émanant des établissements d'enseignement et de recherche français ou étrangers, des laboratoires publics ou privés. 


\title{
PATTERNS OF INTENTION: \\ OBERKAMPF AND KNOLL AS SCHUMPETERIAN ENTREPRENEURS \\ Elen Riot
}

\begin{abstract}
Presented here is an analysis of Schumpeter's interest in political economy, as it relates to his use of history to investigate economic change and capitalism. This aspect of Schumpeter's work - referring to style and involving a range of moral and aesthetic considerations - is largely neglected in entrepreneurship studies despite his influence on the discipline. This paper argues these considerations are essential to understand Schumpeter's entrepreneur and the role of creative destruction in rejuvenating capitalism. However, his theory also involves political inclinations and choices, such as elitism and a fear of declinism, both of which are more typical to conservative not destructive worldviews. To illustrate my argument I examine and describe two cases, those of Oberkampf and Knoll, the latter a rough contemporary of Schumpeter. The findings point to the central role of political economy in past and present debates about the political role of entrepreneurship in society, suggesting a need for further attention to the zeitgeist (spirit of the time) in future research.
\end{abstract}

\section{Introduction}

Although Schumpeter's entrepreneur is highly popular in entrepreneurship studies, this canonical status may prove distracting in explaining Schumpeter's true intention: specifically, his effort to refute Marx through his own method of investigation, coined political economy. In both Schumpeter and Marx, the concern is an ambitious and generalising one: to account for the ideas, forms and values of a given period. In our post-industrial age, entrepreneurship studies seem curiously wary of committing to the kind of general pictures thrown up by concerns with political economy. It is toward recovering such a concern that this paper is committed. Specifically, its goal is to reintroduce the missing dimensions in Schumpeter's theory and make more explicit political economic views in realist descriptions of entrepreneurial ventures.

To demonstrate this, I first position Schumpeter's Triad - the entrepreneur, creative destruction and capitalism - as the pivotal point of his political-economy system. I then examine the cases of two historical entrepreneurs, Oberkampf and Knoll, placed respectively at the beginning and at the end of the period conceived as the industrial revolution. I present them in Schumpeter's style to better embody his arguments. I hope to situate where his emphasis lies and what other dimensions tend to be downplayed. I also focus on 
Schumpeter's late views on the decline of capitalism. I conclude by arguing for a reintroduction of history and political economy as key dimensions of entrepreneurship studies, as was done in Schumpeter's work. This involves taking open positions, central in public debates, about the present age of capitalism and role entrepreneurship plays therein.

\section{Entrepreneurship, Economic History and Political Economy}

I first present entrepreneurship theory and Schumpeter's influence. Then I insist on missing dimensions which were present in Schumpeter and may often be missing today.

\subsection{Entrepreneurship Theory and Schumpeter}

Schumpeter's work has been influential in entrepreneurship studies - especially the figure of the entrepreneur as the "man of action" capable of making "creative destruction" happen by exploiting the full potential of radical innovation. I shall see that, despite (or because) the success of this theory, the rest of Schumpeter's political economy remains largely concealed in entrepreneurship studies, making his popularity an ambivalent one. According to Aldrich (2010: 454), "Subsequent work on entrepreneurship has borrowed a great deal from Schumpeter, but the field has also forgotten much of what he proposed." Because in entrepreneurship theory Schumpeter's approach is often detached from the dimensions pertaining to political economy, aspects of his thinking related to the entrepreneur, creative destruction and the fate of capitalism are ignored. Yet these aspects are quite important for understanding entrepreneurship, as well as organizational theory more generally, because they address the nature of political and economic transformation (Stern and Barley, 1996). For example, the choice of method in launching an entrepreneurial venture implicitly reflects a prevailing moral stand in terms of what we think is good and bad for society, even when we claim to be agnostic in that regard (Anteby, 2013).

In the following table (Table 1), I identify five approaches that borrow from Schumpeter's work and combine it with vastly different theories.

Insert Table 1 about here

Surprisingly enough, only Penrose mentions Schumpeter's large-scale ambitions in studying the role of the entrepreneur in history. She does it to contrast her more modest views of 
leaders in relation to the growth of the firm, and the constrained nature of change in organizations, with Schumpeter's "flamboyant entrepreneur", whose fate is to rejuvenate society as a whole.

More recently, in his revival of the historic, micro-level approach, Gartner $(1988,1985)$ uses the Schumpeterian entrepreneurial figure, and in doing so might be said to touch at least on Schumpeter's material historicism, to help expand upon the ways in which a venture is brought into being, an approach that had been typically downplayed by economists (Aldrich, 2010: 452; Smelser and Swedberg, 2010), with the exception of the socio-economic stream (Casson and Godley, 2005; Lippman and Aldrich, 2014). As noted by Jones and Wadhwani (2007: 351), Gartner brought an important change in the dominant approach at the time. Yet his use of Schumpeter is limited to empirical, micro-level historical facts and details, and whilst these dimensions are not absent from Schumpeter's work (he does take examples from real-life entrepreneurs at times), he also takes cues from far broader settings. For instance, Schumpeter regards the entrepreneur not only as an organizer or a merchant trying to sell such things as soap, but also as a (temporary because always untimely) world leader. His interest is in always looking for the wider resonance of the entrepreneur: events are held in dynamic patterns which, through interaction and over time, constitute political and economic evolution (Stern and Barley, 1996).

\subsection{Missing Dimensions: Economic History, Historiography and Political Economy - Marx's inheritance}

Schumpeter's originality lies with his embedding historical economists' ideas about entrepreneurship within a theory of endogenous change and growth within capitalist societies (Wadhwani, 2010: 347). It was an argument in line with what Wadhwani calls "German cameralism" (a group of economic historians including Sombart or Schmoller (Ebner, 2006)); but mostly, it was an attempt at using Marx against his own doctrine, and defending capitalism as the best system by showing "founding fathers". As Popp and Holt argue, telling the story of an entrepreneur gives one "a grip over events", but it also explains how facts may become "concealed by the teleological power of [individual] narratives - powerful because it draws so much "from the current twenty-first century concerns with commercial growth and flourishing, and because of the strength of the concepts and generic strictures underpinning it (...)" (2013: 53). The limitations in objectivity that appear here are not Schumpeter's but our 
own. Therefore, concerns from both the past and the present must be carefully examined. The interpretation as well as the original sources should be treated with a prudent compunction: the latter with hermeneutics and the former in relation to our common implicit assumptions in political economy.

Schumpeter's originality lies with his embedding historical economists' ideas about entrepreneurship within a theory of endogenous change and growth within capitalist societies (Wadhwani, 2010: 347). That was in line with what Wadhwani calls "German cameralism" (a group of economic historians including Sombart or Schmoller (Ebner, 2006)); but mostly, it was an attempt at using Marx against his own doctrine, and defending capitalism as the best system by showing its evolution in historical facts. Historicists conceived the entrepreneur as a distinct agent of economic and historical change - a perspective that differentiated them from both the materialist dialectics of Marxist views of history and the a-historicism of the classical economists (Swedberg, 1998). What Schumpeter aimed for was for a mutual accommodation of history with the theoretical assumptions (like optimum equilibrium) buoyant in classical economic theory .

Personally, I believe that there is an incessant give and take between historical and theoretical analysis and that, though for the investigation of individual questions it may be necessary to sail for a time on one tack only, yet on principle the two should never lose sight of each other (Schumpeter, 1949: 75 as quoted in Wadhwani, 2010: 346).

Accordingly, Schumpeter used the entrepreneur, creative destruction and capitalism (as an economic system) as three dimensions that could be described empirically whilst also belonging to a system - that of the homeostasis of the economic optimum equilibrium. Therefore, his three key concepts are grounded in three disciplines of socio-history, economy and historiography (the history of ideas in economy) as illustrated in the table below (Table 2).

Insert Table 2 about here

Schumpeter makes clear choices: he insists on the role of multilevel forces (and of the individual). His dynamic approach may be related to dialectics, just as the term "evolution" is 
traced back to Darwin. He is, in fact, battling with Marx in recombining these same ideas, using Marx's method to prove him wrong.

In the endeavour to use Marx's method to prove him wrong, Schumpeter enlisted the entrepreneur and his/her force of creative destruction to defend the equilibrium of the capitalist system, its dynamics, and evolution as positive forces. Schumpeter believed Marx "failed to acknowledge the contribution of men of superior energy and intelligence" (Prendergast, 2006: 254). Marx fails to recognize that his view of the capitalist mode of production as driven by one single law (the tendency of the rate of profit to fall) is a theoretical impasse, since capitalism has so far survived all its cyclical crises, contrary to his own predictions. Empirically, this shows the capitalist system is sufficiently homeostatic to maintain its equilibrium, something realized through the engine of innovation, and the helm of which was the figure of the entrepreneur.

\subsection{Patterns of Intention: From Schumpeter to Baxandall}

Although historical economy, economics and political economy are essential dimensions of Schumpeter's theory of entrepreneurship, reintroducing the whole body of his research to entrepreneurship theory may prove an overwhelming task. Moreover, as it was itself historical and so part of his own contemporary debates (Schumpeter died in 1950), it may also be partially obsolete. Yet, without awareness of these wider conditions or Zeitgeist (spirit of the time), Schumpeter's theory can easily be misunderstood or simply mentioned as a tribute, in passing.

One way to reintroduce history, economics and politics in the spirit of Schumpeter might be to invoke his theory of style and aesthetic vision - a dimension of his work very seldom mentioned. This can be done by comparing his concepts about historical change with those of a contemporary art historian, Michael Baxandall (1933-2008).

Schumpeter and Baxandall both appropriated and transformed Marx's dialectic materialism and historical method. However, because their objects and disciplines differ, their concepts prove complementary for entrepreneurship studies as they both address political economy from two distinct disciplines and argue their position from two different periods of time (respectively, 1910-1950 and 1970-2010). 
Like Schumpeter, Baxandall is keen on breaking away from both monographies (where individual or national talent is overvalued) and aesthetic laws and principles (de-correlated from material reality). Rather, he balances an individual dimension (the painter's invention and "patterns of intention") with a collective dimension (the common knowledge of the time), making it possible to assess problems and solutions in representations. Aesthetical problems are related to a shared culture among viewers (creators and spectators) based on a "common knowledge version" of the sciences, techniques and trades of the time. He calls it "the period's eye" - his key example being the Quattrocento. Both authors insist on finding a fit and a balance between individual and collective action.

Much of what we call 'taste' lies in this, the conformity between discriminations demanded by a painting and skills of discrimination possessed by the beholder. We enjoy our own exercise of skill, and we particularly enjoy the playful exercise of skills which we use in normal life very earnestly. If a painting gives us opportunity for exercising a valued skill and rewards our virtuosity with a sense of worthwhile insights about that painting's organization, we tend to enjoy it: it is to our taste. (Baxandall, 1972: 34-35)

Schumpeter is similarly interested in this 'tasteful' coming together of skill and discrimination, finding for example, a deep sympathy between the capitalism of his period and prevailing business dress: "The evolution of the capitalist style of life could be easilyand perhaps most tellingly-described in terms of the genesis of the modern lounge suit." (Schumpeter, 1950: 126).

Because Schumpeter equates the fate of capitalism to that of culture and civilization, his approach is consistent with an aesthetic one (Aspers and Godart, 2013) in that it focuses on the explanation of the endogenic forces that create and maintain the harmony of the capitalist world. He feels capable of combining different schools in using inference to elicit causes and effects governing the occurrence of events. However, finding an equivalence between "ideas" and such "patterns" as the entrepreneur and creative destruction is quite complex, since Schumpeter is looking for a middle ground to reconcile Walras (the laws of classical economics) and the German historic school and the focus on crises and disequilibrium (Smelser and Swedberg, 2010; 2005; Perroux, 1965). 
As illustrated below (Figure 1), for Schumpeter, the capitalist system has three central characteristics: individual leadership, creative destruction (dynamism) and evolution.

\section{Insert Figure 1. about here}

The fact that Schumpeter centres on a timely equilibrium combining facts and concepts via the entrepreneur's vision makes his system markedly close to Baxandall's view of how the artist works when she or he achieves a breakthrough, as illustrated below (Figure 2).

Insert Figure 2. about here

Baxandall insists on a key difference between the artist- pioneering with his "patterns of intention"- and the spectators of his time- following the period's eye-. That makes his approach quite similar to Schumpeter's views. The artist's specific role is to invent new forms, introducing disruptions that may transform existing dominant representations into past fashion. Taking the case of Chardin's use of light in his painting, A Lady Taking Tea, and refering it to both Newton's physics, Locke's empiricism and Diderot's Enlightenment philosophy, Baxandall (1985: 75) describes the painter's "patterns of intention" as dual. It is a specific problem-solving process coined by Delacroix as "a process, the attention to a developing pictorial problem in the course of activity in a pictorial medium". The terms of the problems and the solutions (made tangible in an object made of oil on canvas) are very specific to the discipline. Yet, an avant-garde, inventive painting also corresponds to a much general pattern, the ebbing of a wave, a form of disruptive novelty in all systems of thought which painting expresses in its own way. Although Baxandall acknowledges it may seem "tactless to link such incommensurable universes" as a "style of paiting and a position in philosophy or science", it provides a unique insight for when looking for solutions on the easel before him, painters like Chardin or Picasso are also immersed into the scientific culture of the time since "painters cannot be social idiots".

Both Schumpeter and Baxandall chose to look back at this "breakthrough moment" in an effort to analyse and explain the "rules" of the system of social change: "Schumpeter's approach to history is sequential as opposed to structural (historical institutionalism, Baumol or Stinchcombe) or constitutive (cognition, identify, as in effectuation). Its focus is on knowledge: "knowledge spill over, new market emergence" in relation to "temporal 
boundaries of opportunities" and "relationship between entrepreneurship and change in the field.” (Kipping, Wadhwani and Bucheli, 2014: 318).

However, because there is little regularity in the events and few causalities, it would be a mistake to believe facts are socially constructed. So Schumpeter is in opposition to, say, the constructivism of Hayden White (1973), who equated historical representations to fictional narratives; or that of Frank Ankersmit (1983), who presents political economy in history as a picture (and different styles of vignettes). Although Ankersmit (1996) also claims Schumpeter's heritage, constructionists like him have a different view of the general perspective to account for a great variety of interconnected facts in an accurate way. Schumpeter's claims his approach accurate because it offers a reading of empirical facts that can be tried against these facts.

Schumpeter regularly deplored his fellow economists' lack of vision for this very reason: their theories could hardly be tested against the facts in political economy because they remained too narrowly focused. He claimed: "It is much more difficult to visualise fully the really important factors and features of this process than it is to formulate their modi operandi once we have (or think we have) got hold of them. Vision (and all the errors that go with it) therefore plays a greater role in this type of venture than it does in the other" (Schumpeter in Prendergast, 2006: 269). Schumpeter also blamed them for neglecting important facts: "The failure of both the classical economists and Karl Marx 'to visualize clearly entrepreneurial activity as a distinct function sui generis'-a distinction Schumpeter himself always underscored-was a crucial flaw in their analysis of capitalism." (in McCraw, 2007: 255). Both missing dimensions could be attributed to a lack of investment in the inferential analysis of facts, in going back and forth between empirics and concepts.

For Baxandall, history is essential to help us understand - via inference - what a Quattrocento person was "distinctively equipped with" when looking at a painting ((Baxandall, 1972: 40). He assigns a role to the historian confronted with the object:

An old picture is the record of visual activity. One has to learn to read it, just as one has to learn to read a text from a different culture, even when one knows, in a limited sense, the language: both language and pictorial representation are conventional activities. (Baxandall, 1988: 152). 
Schumpeter has to deal with similar concerns with accounting for material facts from the past, a problem Baxandall identifies with that of inference:

(...) if we think or speak of a picture as, among other things, a product of situated volition or intention, what is it that we are doing? So, the question is, within limits, one about the historical explanation of pictures, (...) the 'inferential criticism' of pictures (...). (Baxandall, 1985: 27).

As Schumpeter would not choose one single school in economics but eclectically borrowed his concepts from all, he still had to arrange them, as a composer might a tune. In his case, the tune had an important role in providing harmony. As Baxandall reflects upon pictures, such key tunes tend to be indirect; for they do not address the picture itself but its affect on an historically located audience (Ibidem, 36). That explains why Schumpeter's theory should be referred to the perspective of his period: it was meant to be an actual reflexion on the present age of capitalism, not an economic abstraction or an account of its origins. Schumpeter is keenly aware of the situated nature of his analysis: "Our argument rests on (abstractions from) historical facts which may turn out to belong to an epoch that is rapidly passing." (Schumpeter, 1939: 144).

\subsection{Schumpeter's Declinism and the Influence of the Viennese Taste for Decadence}

Because in entrepreneurship theory Schumpeter's approach is often detached from the dimensions pertaining to political economy, aspects of his thinking related to the entrepreneur, creative destruction and the fate of capitalism are ignored. Yet these aspects are quite important for understanding entrepreneurship, as well as organizational theory more generally, because they address the nature of political and economic transformation (Stern and Barley, 1996). For example, the choice of method in launching an entrepreneurial venture implicitly reflects a prevailing moral stand in terms of what we think is good and bad for society, even when we claim to be agnostic in that regard (Anteby, 2013). The Zeitgeist is all pervasive, whether it is acknowledged or not

The following table (Table 3) provides a sample of the questions Schumpeter had in mind while building his theory of the entrepreneur as a solution to capitalist accumulation (and stagnation).

Insert Table 3. About here 
Importantly, Zeitgeist, translated as "the spirit of the time," is a term borrowed from Hegel and Carlyle. What he observes was the decline of a certain form of elite, an aristocratic class unable and unwilling to innovate, and who would preside over a decline. The entrepreneur, superior to all others, takes on the role of leader. In his heyday, Schumpeter used the metaphor of the palaces he may have observed in his native Vienna, writing: "the contents of classes are changing like a hotel or an omnibus, always full, but always of different people", the inherited privileges are leaving, making way for those who have earned it through their entrepreneurial character. ${ }^{1}$

\section{Method and Data}

In the following section, I refer to contemporary realist approaches used in entrepreneurship and organizational history when presenting case-studies (3.1.). I then allude to Schumpeter's case study of one entrepreneur, in order to expose his method (3.2.). Finally, I justify the choice of two case-studies to test his method and compare it with contemporary approaches (3.3.) in an effort to situate Schumpeter's view on the role of entrepreneurs in relation to the social system in general and questions on political economy.

\subsection{A Method in History}

The realist approach to using history in case-studies may act as "an umbrella concept for analyses that aim at reconstruction of past events by using historical sources (...) (it) means accurate and authentic reconstruction of events and processes from the perspective of an external observer" (Vaara and Lamberg, 2016: 621). This contrasts with two other approaches to past facts: interpretive history (inspired by social constructionism) and poststructuralist history (radical deconstruction of history, emphasizing the importance of discourse).

\footnotetext{
${ }^{1}$ In later years, Schumpeter becomes pessimistic about the possibility for entrepreneurial leadership, and somewhat ungraciously blames Marx for turning capitalists against themselves. This reversion in Schumpeter's thought is quite striking, although in many ways, it can still be attributed to his Zeitgeist, according to Hirschman:
}

Schumpeter writes: “ (...) capitalism creates a critical frame of mind which, after having destroyed the moral authority of so many other institutions, in the end turns against its own; the bourgeois finds to his amazement that the rationalist attitude does not stop at the credentials of kings and popes but goes on to attack private property and the whole scheme of bourgeois values." ... This sort of vision may have appealed to Schumpeter, who, after all, came right out of the Viennese fin-de-siècle culture for which self-destruction had become something totally familiar, unquestioned, selbstverstandlich. (Hirschman, 2013: 223). 
Its principles are quite in line with what we already presented of Baxandall's materialist method in art history. For instance, McLean, Harvey and Clegg identify: "five key principles that inform historical organization studies - dual integrity, pluralistic understanding, representational truth, context sensitivity, and theoretical fluency (...)." (2014: 5). These principles can help us articulate empirical facts and concepts. More specifically, if we admit history can be used alternatively to "evaluate, explicate, conceptualize and narrate" as four conceptions of history in organization studies (McLean, Harvey and Clegg 2014: 21), our goal here is to elicit more information about the role of concepts (relative to issues in political economy) in interpreting entrepreneurs' actions.

This may stand in contrast to another contemporary approach: constructionism. For instance, Ankersmit (1983: 94) offers a narrative realist interpretation of the narratio (in history). He prefers to view history as "a coordination of objects on its representation of the world" (1995: 214) instead of a "narrative prose" (White, 1973: 2). However, Ankersmit sees aesthetics as the only tertium for a political economy, otherwise "dissolved into economics and literary theory (that is, into deconstructionism) (1996: 97)" as it may provide "a maximum continuity between money or language and the world" (Ankersmit, 1996: 98). The materialist-realist tradition we follow here insists "the domain of the representation and the represented (can be) defined in terms of each other" (Ankersmit, 1996: 100) and so aesthetics (the world of art) is not outside "the world that is given to us in experience" (Ankersmit, 1996: 100). It is part and parcel of political economy and the questions raised by entrepreneurial ventures. This realist stand grounds our analysis of Schumpeter's political economy, underlying his entrepreneur and creative destruction.

\subsection{The Choice of the Cases}

Jones and Wadhwani (2007: 307) prompt us to "re-historicize" research, in line with Schumpeter's work. We follow this advice by situating Schumpeter's research in his time and restituting his logic of analysis. As Baxandall (1985) pointed out, in reconstructing the pattern of an "intentional object" the analyst mostly delves into relations, such as those between: the problem and its solution; the problem and its environment; and our own analysis and the impression made upon us by both the picture and its description. This is why our method to test Schumpeter's entrepreneur necessitates pictures of entrepreneurs as close as possible to his description. Schumpeter's reflection is usually situated at the meso and macro levels; 
therefore, he seldom takes the case of individual entrepreneurs. Namely, he refers to the entrepreneur as part of his theory of "individualism," but he never provides fine-grained descriptions of specific entrepreneurs.

In their works examining the history of the situated concept of "entrepreneur," both Verin (1982) and Boutillier and Uzinidis (2014) contrast Schumpeter's approach to that of Smith, Cantillon and Say. All three of them use specific cases and depictions in their explanation of the capitalist system whereas when Schumpeter does so, it is for a purpose. For instance, he takes the case of Richard Arkwright, a British textile manufacturer who was a pioneer in the use of technology - namely, the sewing machine called the "Jenny" - in large factories. We believe the interpretation of the case in Business Cycles (1939) is an answer to both Proudhon and Marx (2008 (1846), who interpreted it before Schumpeter. More precisely, Marx reinterpreted Proudhon's description of Arkwright (they both pointed out his ruthlessness); and Schumpeter corrected them both (pointing out the man's triumph over the old world). This was an exception, however. Possibly because an individual case was an easy target for observing contradictions, Schumpeter would generally avoid them in his demonstrations. This is why using fine-grained descriptions in case-studies may prove a good test of Schumpeter's theory; he praises such method yet repeatedly fails to test his theory against it. It may be the only observable way to identify the nature of the entrepreneurial style, the uniqueness of his innovation, and the influence of the changing ages of capitalism. Namely, for Schumpeter, it is a matter of interpretation - a way to illustrate his "pattern of intention." For this, we had to find fitting cases (Dawson and Hjorth, 2012; Hjorth, 2003; Hjorth and Steyaert, 2004; 2009) and use different historical sources which would fit with Baxandall's aesthetic method.

As pointed out by both Holt (2007: 153) and Bricknell (2007), a contemporary realist approach to history involves both: "the examination of evidence (...) and the cause and effect between those facts in order to understand why things happened. (...) while the past is the immensity of everything that has happened, history is what we know of the past [hermeneutics]." (Brichnell, 2007: 109). This involves setting limits to one's account of the phenomenon to be studied and the knowledge to be attained.

In this case, triangulating the data to elicit common patterns in micro-analysis and finegrained descriptions proved essential in fact-checking the nature of the entrepreneur's creative 
destruction; his patterns of intention (Baxandall, 1988), or any causal system of explanation in the two case-studies. Using inference as a method guided by hermeneutics was a guide for reading and explaining in two different styles: that of Schumpeter and that of Baxandall. One reason is that anterior historical accounts about successful entrepreneurs seem marked by the ideology of "the century of the leaders" (Cohen, 2013) as illustrated in Schumpeter's own writing. On the contrary, a more contemporary account, like that of Baxandall, captures complementary dimensions, but it is not sure it can build a clear and convincing picture of the entrepreneur and creative destruction.

\subsection{The Data: Two Cases}

The two cases of entrepreneurs were chosen according to several considerations. They were successful in helping to change their industry at one point. Sufficient data were available to critically assess the sources (See table 4 below). They were active in an industry which Schumpeter knew well, both for family reasons (Allen, 1991; McCraw, 2007; Swedberg, 1991) and because he famously described the textile industry during the industrial revolution (2003 (1939); 2006). Finally, they belong to the beginning and the end of that age respectively, which provides an occasion to test Schumpeter's theory about the decadence of capitalism.

Insert Table 4 about here

Our reading of the two cases in parallel was meant to elicit Schumpeter's assumptions and the missing dimensions in his approach in relation to what contemporary case-studies might find essential features of entrepreneurial ventures. Our investigation was devised as a test of his conceptual framework. Therefore, in the various sources we gathered, we sorted out the recurrent elements that fit in the three main categories (the entrepreneur, creative destruction, and the fate of capitalism) and those who proved missing or contradictory with his approach.

Specifically, the methodology involves a number of elements, viz. (i) the critique of each text to determine its external as well as internal validity; (ii) a triangulation of various sources to reduce bias and increase confidence in the robustness of the research results; and (iii) an iterative process (often referred to as the "hermeneutic 
circle"), which situates texts within their historical contexts and in relation to other texts (Kipping, Wadhwani and Bucheli, 2014: 312).

We use discriminating (secondary) data found in historical accounts to serve as an interpretation, as well as primary data (such as archives). This is justified because: "Given the incompleteness of historical sources, the use of secondary sources in this process can be seen as a matter of convenience as well as a matter of methodological adherence to source heterogeneity." (Kipping, Wadhwani and Bucheli, 2014: 318). On the other hand, numerous accounts used in our study fit in the hagiographic versions of "self-made men" because their success has made them institutions. Both the Oberkampf and the Knoll families were heavily invested in the pantheonization of the founding fathers.

\section{Two Cases: Oberkampf and Knoll}

I first describe the industry which is related to fashion and changes in regimes of value and therefore concerned with political economy. Here, I remind my reader of Schumpeter's pun regarding the evolution of the capitalist style which could be "tellingly described in terms of the genesis of the modern lounge" (Schumpeter, 1950: 126). I first tell the entrepreneur's story in a 'Schumpeterian style' then introduce the missing dimensions which a contemporary account would include.

\subsection{A Type of Trade where Political Economy Matters}

In the following description, I present two parallel entrepreneurial figures who have many features in common with Schumpeter's archetypical entrepreneur (see table 5 below). Their personality, their trade and their position in the world may correspond to both the zeitgeist described by Schumpeter and the "patterns of intention" described by Baxandall.

Insert Table 5 about here

As I am about to examine how each story actually fits Schumpeter's "patterns of intention", I shall also look for the transformation of the capitalist age between the two periods of time. I may already observe an important shift in language, in that the "decorative arts" (in the protoindustrial age) become "design" in the modern functionalist world of industrial production. A 
comparison of the two periods of time should reveal any potential signs of decadence in the "style of the modern lounge", if present. That is, I shall observe whether or not the transformative action of the entrepreneur is weaker (i.e., both "less destructive and less creative") in Knoll's case than in Oberkampf's.

\subsection{Oberkampf}

Christophe-Philippe Oberkampf founded the Toiles de Jouy, one of the largest French manufactures to emerge in the Mercantilist age. The business was founded in the 1760s and did not survive the third family generation.

\subsubsection{Oberkampf, a Schumpeterian Entrepreneur}

Oberkampf was born in Baden-Württemberg in 1738, in a family of Protestant textile craftsmen. He spent his youth learning his trade in Germany and Switzerland, then emigrated to France after the ban on calicos was lifted. This ban, meant to protect Northern producers of wool, Lyon "canuts" (silk workers) and the import-export trades of the French East-Indian company was passed in 1685. As a result, the ministers of the King were concerned the country was lagging behind its European competitors. They used the lift of the ban against Protestants (caused by the Edit de Nantes in 1686) to invite skilled workers and tradesmen to return and develop the trade. Oberkampf was a skilled worker, specialized in engraving (the noblest of all skills since it was equally exerted by painters). He wrote a letter advising his son when he was about to hand him the business:

If you want to understand my business, you really must learn all the different parts of it; (...) to do so, you must learn how to do each specific part (of the production chain) by yourself. I had you start by drawing and engraving, the most essential parts to better train your taste and be able to tell good from bad. After that, comes the knowledge of colours which one may learn at any time... The printing part is the most essential for the success of the good, and even to garance (bright red), them well, because this process is key to the beauty of colours. If not, the fault will have no cure. Then, one must know in which part of the meadow where the cloth is laid, because this brings the product to its utmost perfection. All these things cannot be learnt without doing them by oneself. One must also be able to assemble the basins for the blue bath... The direction of the brush is not indifferent to replace a missing worker. All these things are of the utmost importance so as to replace those in charge of them. Otherwise, you are 
dependent on everyone, and you have no choice but to trust what they say. (Dewerpe, 1990: 30).

The nature of the Oberkampf's creative destruction derives from his various skills (and new ones provided by his next of kin such as his nephew, inventor Samuel Widmer); the protestant network that sourced his cloth via all European East-Indian Companies, throughout England, and in the Netherlands; and his attention to fashion (in relation to the European "calico craze" of the time). He located his business in Jouy-en-Josas, a village between Paris and Versailles. Oberkampf called himself "the creator of (a) new taste" (Gril-Mariotte, 2015), and that's what made the firm a success. Its reputation was first built on highly accurate copies of Indian designs; but in a little over ten years it was printing large cameo designs in rococo style from copper plates and depicting a variety of images, from outdoor or hunting scenes to copies of naturalist Jean Lamarck's encyclopaedia of plants to popular events of the day, with titles such as 'American Independence' and 'The Marriage of Figaro'.

Political content was a key component of the culture in times of changing regimes, and this was initially reflected in Oberkampf's prints. However, the factory eventually abandoned political subjects because the costs of the design, and especially the engraving, could be offset only if the design was printed for several years. The last two such designs were titled, 'Louis XVI, restaurateur de la liberté' and 'La Fête de la Fédération'. During Napoleon's Empire, imperial emblems were never used as patterns. Yet its designer, Jean-Baptiste Huet, did present 'The monuments of Egypt' after the Emperor's expedition and during the wave of Egyptomania. (Gril-Mariotte, 2009: 79).

Oberkampf had soon become famous, and was knighted by Louis XVI. “Oberkampf's goods acquired a social cachet as his customers were obviously the most distinguished and influential people, notably the Duke of Gontaud (Lauzun) who boasted in the salon of the Duchess of Choiseul in 1776 of having given Oberkampf an oriental design to copy, and that when he succeeded in reproducing it exactly he [the Duke] had pretended the copy was a genuine Indian one and the court believed him.” (Chassagne, 1980: 221).

However, his status was challenged during the French Revolution. "In an account (...) French observers, (...) condemned the global or capitalist business practices of Oberkampf and Réveillon and (...) resented the fact that the monarchy, by granting both men royal status, had 
seemingly condoned these practices. In April 1789, due to a dispute over workers' wages, Réveillon's factory became the site of the first large-scale riots precipitating the Revolution." (Martin, 2014: 51).

After this period, although he was celebrated by the Emperor and Josephine, he stayed as a paternalist entrepreneur and a pater familias in his village of Jouy until his death. At this time, his factory hired more than a thousand workers. It was the second largest in France, after the Compagnie Royale de Saint-Gobain. However, he and his heirs engaged in politics and defended patterns and protectionism via a series of libels and petitions. Although little is said in official memoirs and accounts, the archives show the importance of this commitment in influencing political and economic choices in a turbulent time in order to prevent new entrants.

\subsubsection{Oberkampf, Baxandall Style}

First, Oberkampf is a successful entrepreneur, but he is really one among many. In the arts décoratifs (decorative arts) - and in cotton fabrics in particular - a group of Protestant entrepreneurs had been invited back into France to import the technical skills and trade networks they had developed abroad, during the Counter-Reform. The French East Indian Company, --- by nature a highly speculative import-export trade - was in decline, but the "calico craze" suggests demand for printed cotton did not falter. Not only did Oberkampf provide perfect copies of the toiles d'indienne (calicos), he also offered high profits to his investors as the firm faced major risks: a revolution, a large flood, the English ban during the Napoleonic wars, and the innumerable imitations of all of its designs. Three specific aspects of Oberkampf's success support institutional analysis of the field at a multi-level. First, Oberkampf's "raw" production depends on partnerships with corporations of craftsmen and tradesmen in dress and home furniture (known in Paris as 'arts décoratifs'). He copied with taste the beautiful Indian printed patterns, appropriating traditions present in the Silk Road since Antiquity and including in his own business such networks as the engravers of Diderot 
and d'Alembert's Encyclopedia (the Academy of Fine Arts), the Armenian traders of Marseille, and Protestant Elite investors. The archives show that the financial structure of the firm was highly speculative. Oberkampf was more of a tradesman than an industrialist: less than 10 percent of the firm's assets consisted of fixed capital. He and his partners in all byproducts secured both quality products and time to market. His ability to recycle copper plates with prints is one of the tricks that may illustrate the central role of bricolage to limit the risk. For instance, a 'balloon mania' developed in the visual arts and then spread to the decorative arts, from interior decoration to numerous fashionable 'objets d'arts' of the late eighteenth century. The 'balloons' of the Montgolfier brothers became a hit in fashion (Petitcol, 1993). Oberkampf imagined different possible arrangements of the pattern and had at least three pieces of monochrome upholstery printed with balloon motifs at different prices for different markets and catchment areas in France. In later prints, the landscape was recycled and the balloons disappeared.

Second, the archives reveal the importance of nature as a constant source of inspiration for Oberkampf's collaborators in the arts and sciences. The river Bièvre and the fields were used to clean and dry the cloth and to inspire/create patterns. It was a group research which was centred on observation rather than creative destruction via the invention of new types of machines. To celebrate how Europe had caught up with India in about three generations, Oberkampf had Huet draw a special toile de Jouy called Les travaux ("the works") describing his manufacturing process in detail at all stages of production. The precision in depicting the machines and work processes is a homage to both Hesiod's Theogony and the contemporary "Encyclopedia" project by the French philosophers of the Enlightenment like Diderot and D'Alembert. One is struck by the presence of the rural environment of the village as part of the factory in Huet's toile de Jouy. Many other toiles made prints out of the grass, flowers and 
trees in the fields where the cloths hang out. It was in line with Rousseau's approach to society.

Thirdly, the fact that Oberkampf did become part of "the Elite" says very little about his socialization, since there were many "elites" as they kept changing at the time. Besides, Oberkampf wanted to enforce his own vision of society in accordance with his Protestant work ethic. He had soon created his own unit of production in a village between Paris and Versailles. He settled his family and his factory by the river and lived among his workers in a form of "pastoral world". Thus, Oberkampf's distance from the rapidly passing elites of the time secured him a form of independence. He spent most of his time in his production units. Oberkampf was never in danger because he had become the head of the villagers' community. the paternalist figure among his workers. Chassagne describes Oberkampf as a man with a strong Protestant faith and a stern code of discipline, exerting a paternal authority. During one workers' strike in 1792 (during the period of the French Revolution called "the Terror"), Oberkampf lectured his printers:

Fathers should set an example to their children so that they grow up to love virtue and their work and are always happy (...). It is violence that brings scarcity; food is in plentiful supply where markets are free and law and order prevail. (Dewerpe, 1980: 73).

Oberkampf's prints celebrated the present and are still fashionable today, as they are associated with the Ancient-Régime, Marie-Antoinette in Versailles and le Clos-Lucé. As an entrepreneur of fashion, he achieved success in celebrating the "Period Eye", an enlightened monarchy combined with his Protestant Quaker values. He hired historiographers, painters 
and sketchers to ensure that his mark would last. Indeed, this is quite a paradoxical success, among many others, for a member of the "bourgeois elite" that Schumpeter celebrates. His firm, its aesthetics and its ethics did not survive the later phases of the industrial revolution (the period of Richard Arkwright and his Jenny). Yet his heirs, the Mallet family, remain an affluent family to this day, invested in the Jouy-en-Josas city council and in the museum of the Toiles de Jouy.

\subsection{Knoll Inc.}

Knoll's business was founded in New York City in 1938 as an upscale line of designer furniture in a time when trade with Europe was blocked due to the war. The firm developed via large contracts, then expanded into an industrial production and distribution network in the US, Japan and Europe, defending an "international" design style.

\subsubsection{Knoll as a Schumpeterian Entrepreneur}

Hans Knoll was born in 1914, the heir of family firm specializing in furniture and design. His uncle Willy Knoll was a famous architect. He left Germany in the 1930s and began selling furniture in New York, then Michigan. Then he met Florence Schust ("Shu") who had worked with famous European designers during her studies in Ivy league colleges pioneering modernism. These included Eero Saarinen, Harry Bertoia and Ludwig Mies van der Rohe. They married and founded their firm, Knoll Inc. during the war.

Hans Knoll was always on the look-out for resources, whereas Florence Knoll was more engaged in the production process. Both acted as pivots at the centre of a close circle, composed of various groups such as designers, clients and investors.

As Yves Vidal, who was hired by Knoll in 1952, recalls:

We had no cash, but a very large contract (to make the business unit profitable, because the contract made it just break-even, synergies were exploited in private home interior design). This was our major success, the whole impulse came from France and soon 
residential furniture represented half of our revenues. Knoll furniture was the utmost chic (...) although in the beginning people just did not understand what was sold in the showroom, it looked like an office, with flowers and plants and so people thought we sold flowers. (Shutz, 2010: 62 and personal archives of the author Knoll-France).

Hans Knoll was more daring than his partners:

Major hits were Eero Saarinen's use of plastic and new shapes in the Womb armchair (1948), the Tulip line (1958) and Harry Bertoia's metal collection. (...) The firm becomes the depository of many designers' labelled inventions in line with the partnerships between art and design pioneered by the Deutscher Werkbund. Saarinen's Knoll Model 71 (armchair) first adopted in General Motors's Warren giant complex (5000 employees) would be produced in a great series, Knoll Associated had become the first supplier of tertiary furniture in the United-States, this worried Florence a bit but not Hans. (Lutz, 2010: 43).

When Hans Knoll died at 41 in a car accident, Florence Knoll took over, defending the modernist values that formed the foundation of their firm, Knoll Inc. Knoll Inc. conceived, produced and distributed furniture tapping a new market: that of the large urban headquarters of large corporations. It had a competitive advantage being located in the US, where the market was highly dynamic. The firm expanded into the furniture markets of a mass consumption society. Products could be tailor-made or standard. They could include more craft or more technology in a combination of European, American and Asian arts and crafts. It also used local materials.

The planning unit was working with professionals (boards and public relations) in large corporations:

The Planning Unit ... took formal inspiration from modern architecture, which many perceived as cold and barren, and accommodated the need for visual stimulation by incorporating colour and texture into the interior. ... The key elements of the Planning Unit design process were the client presentation tool known as the paste-up and the aesthetic of the Knoll Look. (Tigerman, 2007: 67) 
Some hit-products, such as chairs, are produced on a large scale and combine high quality and competitive price: "The factory worked for both the planning unit (tailor-made) and the showrooms (the equivalent of ready-to-wear in furniture)." It was innovative:

The Saarinen armchair for General Motors was manufactured in thousands, and it was covered by the Transportation Cloth engineered by the Knoll Planning Unit: it was a resistant braided cloth $100 \%$ fibrane, tinged on braids, doubled by latex. Florence Knoll recalls: it was the first industrial textile, which could pass all tests. (...) Knoll was first. (Lutz, 2010: 49).

The showrooms were accessible to the general public:

Shu (Florence Knoll) produced areas defined by Mondrian-like coloured panels. Shu would transform a space with her grid and her big blocks of colour and her unerring sense of proportion. (Personal interview with Richard Schutz at Hofstra, 2008: 79).

The firm pioneered experiential spaces and tight customer relations:

The showrooms were designed by Florence Knoll, (...) She recalls that (...) Each time, one had to make up something new, with the Knoll signature on it (...) the architecture department created their interior design unit, and they would hire my designers. (Lutz, 2010: 38).

Knoll, Inc. soon became integral to the New Deal. By the early 1950s, Hans and Florence Knoll lived in a spacious Manhattan apartment. Hans had become a member of the most exclusive clubs as ambassadors of Bauhaus and new design. They were bringing together Frank Stanton and Nelson Rockefeller with designers such as Harry Bertoia, the Eameses, and the Saarinens. This influenced a host of institutions, museums, universities, foundations and large multinational corporations on both sides of the Atlantic. Knoll design was present from a very early stage in museums and boardrooms alike. Beyond Bauhaus, its most popular creations tend to frame specific work interactions and power relations. They frame public and private space for instance lobbies and boardrooms. This ubiquity illustrates the importance of the symbolic function of an entrepreneur and his/her venture in relation to a specific regime and choices in terms of political economy. In addition to inherited European 
business connections, it was government contracts during World War II that kept the company afloat in the beginning. Major contracts included offices for the United States Information Service (USIS), Secretary of War Henry Stimson, and the United Service Organization (USO) at Times Square. In 1951, the U.S. State Department contracted with Knoll to provide furnishings for houses of American civil servants in Germany. The company also provided the interiors for several Amerikahäuser, American cultural missions across West Germany and embassies in Stockholm and Copenhagen. Knoll's designs were part of an "international style" of furniture design that influenced post-war European developments as well.

\subsubsection{Knoll Baxandall Style}

A contemporary historical account of the Knoll venture would pay tribute to all designers and craftsmen who contributed to the modernist functional heritage.

On his own, Hans Knoll had failed several times to create a firm for lack of funding. He and his team managed to win several bids as a group after he met his wife, Florence, and her designer friends from the most prestigious art and architecture institutions. In the 1940s, they were endorsed by the American government for two reasons: there was a steep decline in European high-style furniture, so they were eager to create a US brand (first). Hans Knoll was a symbol: he was a democrat like his avant-garde European friends, which led him (along with other factors) to leave Germany and break ties with his family. In the post-war period, they were eager to export democracy around the world as a means of global influence. More missing dimensions of this entrepreneurial venture appear in leafing through the archives.

First, in Knoll Inc., Hans Knoll was just a timely pivot in a dense cluster of artists, architects, designers, and traders acting as global entrepreneurs. Knoll Inc. integrated the design, the production facilities, and an important distribution network. They also provided tailor-made services for organizations to create their own space. Group coordination and partnerships were key to this venture, as illustrated in the numerous museum exhibits facilitated by Knoll's architects and designers. 
Second, the field was hyper-competitive, full of independent creators working freelance on contracts for both large factories and small tenders in the arts and craft spirit. What Knoll Inc. as an organization proved especially good at was its integration, which made its reputation spread rapidly. It combined a network of inventors, designers, and architects prominent in art schools and a web of supplies and production facilities that solved all material problems for their creations. Knoll soon started to manage supplies and demands in relation to clients' orders to benefit from economies and scale and scope. The bulk of the archives we accessed deal with this specific issue and the need to secure the best material supplies and find the right arrangements. The nature of space, light, and objects of the world was a shared passion and the intention was not necessarily disruptive of the existing order. Florence Knoll imagined and led the "planning unit", insisting on her role as "a bridge" between all professions involved. To find her place, Florence Knoll insisted on the bricolage dimension of her work, as she designed miniature plans with textile to show the texture, frame and setting:

I would cut the pieces at the proper scale, and it seemed to work by miracle. This was our way to identify the correlation between the colour and the place of objects. It was a very efficient tool for both designers and clients. (Lutz, 2010: 32)

As a matter of fact, this incremental process of adjustment she called "bricolage" rather than "creative destruction" smoothed and unified the "Knoll look". It earned the firm contracts with major corporations such as CBS (Columbia Broadcasting System), Dow chemicals, the Federal Reserve Bank of Detroit, the Federal Library of Midland (Michigan), and General Motors (Lutz, 2010: 33).

Finally, the last important feature we find missing in Schumpeter's picture is the pluralist nature of the elite class to which the Knoll firm belonged. Hans and Florence Knoll did join the modernist political elite circle, but most of their time was spent with friends and colleagues in design studios in relation to the Bauhaus ideals. Hans Knoll spent his time traveling around the world to seek new prospects and open new ventures. He and Florence had also created their own "Pastoral" where he would spend time with workers and designers in his own production unit:

When they [the Knoll company] first came here, the workers almost all spoke Pennsylvania Dutch. It was a dialect like parts of southern Germany and Hans liked that 
because he had been raised in Stuttgart. (Richard Schultz, designer, in Hofstra, 2008: 47).

Florence Knoll used a portfolio of large clients, since she had developed an elaborate consulting technique when she and her team worked for CBS where she was in charge of 25 floors of its headquarters. Based on interviews with employees, she tested and launched a system that would shape the space in relation to corporate identity:

(...) Each of the thirty- five office floors ha(d) a colour-code in one of five colour schemes. The job of floor identification (numbers are not enough) (was) done by a large strong painting or tapestry hanging directly opposite the lift on each floor. (Hofstra, 2008: 92)

This example shows the minuteness of the work involved and the total attention that it required. It received international coverage in the most widely read magazines of the time. The same care and energy were spent in promoting Knoll's image and celebrating the company's history as it became a national "icon of style." Very early in its life, the firm aimed to stand as its "Period Eye." Over the years, exhibitions regularly featured the company's work, for instance Knoll was a key actor in MoMA-curated traveling exhibitions in post-war Europe in cooperation with the Ford Foundation and the U.S. government. In 1972, the Musée des Arts Décoratifs in Paris devoted a major retrospective on Knoll designs. Back in the 1950s, Florence Knoll's work had repeatedly been included in the Museum of Modern Art's "Good Design” exhibitions. In 2012, over forty Knoll pieces were part of the permanent design collection of the museum. Knoll stands as an American icon of style.

\subsection{Capitalism and Decadence}

The two cases of entrepreneurs show a more collective and incremental endeavour than in Schumpeter's theory. His other radical thesis about the decadence of the age and the disappearance of entrepreneurial figures is not supported either by the historical facts I assembled. In his later works, such as Capitalism, Socialism and Democracy (1942) and The Creative Response in Economy History (1947), Schumpeter claims capitalism is in decline along with the role of the entrepreneur. This discovery strikes him to his core of his system, to the point that he changes his mind about Marx and eventually agrees that capitalism is 
doomed - not because of any revolution but because it has lost popularity with the elites. However, this description of the evolution of capitalism as decadent is hardly supported by the evidence comparing Oberkampf and Knoll as entrepreneurs. Hans Knoll, then Florence Knoll, are no less entrepreneurial than Oberkampf. Their venture is no less important, in terms of influence. Their stories differ in content and in style; but the role of innovation, invention and new trade channels is central to both. However, it is striking to see that in both periods, the field was highly dynamic with multiple competing firms. So, this would rather support Baxandall's sequential position, involving differences and discontinuities in economic and cultural contexts. We could also argue that on this point, Schumpeter's stand in terms of political economy contradicts his positions both in economy - due to irregular, unpredictable business cycles; and in historical economics - since he also sported a sequential approach in relation to creative destruction with no moral hierarchy in periods. One key difference between the two firms and the two periods of time is the role of patents, licences and property rights: the Oberkampf heirs fail to defend them whereas the Knolls build a portfolio by acquiring designers' copyrights. They become part of the strategic assets of the firm.

\section{Readings in Economic History and Political Economy}

The comparison between Oberkampf and Knoll - as well as that between Schumpeter's account and a more contemporary approach to historic materialism - suggests that further attention should be paid to history in relation to political economy. As noted by Schumpeter (2006 (1950)) himself in the first pages of his History of Economic Analysis, knowing the history of both facts and concepts helps one to find a filiation and therefore take a position. I first insist on what the history of entrepreneurship and its key concepts would bring and how a realist account would refer to political economy (5.1.). Then, I examine Schumpeter's historical situation in his writing of history (5.2.) and compare/contrast it with our own. I provide more information on Schumpeter's conservative political commitment (5.3.). Finally, I mention several questions that he asked while "inventing" the Schumpeterian entrepreneur (5.4.), as they are central today particularly in terms of public choices.

\subsection{The Need to Rehistoricize}

Schumpeter's work is among the earliest in the field of entrepreneurship, and his ideas are generally mentioned only briefly and possibly misunderstood. A more detailed approach to 
the debates in political economy that introduced the entrepreneur in the first place would certainly contribute positively to the literature. So, I agree that:

One important step toward re-historicizing research on entrepreneurship is to reconsider how the intellectual history of the field is currently framed. Many researchers in the area think of the field as emerging in the 1970s and 1980s and conceive of its intellectual agenda as relatively new. (Jones and Wadhwani, 2007: 357).

This is also true for the method of investigation in early and more contemporary case-studies, since a realist approach of history involves triangulating sources but also dealing with concepts. Fact-checking concepts and their filiation is no less important than being accurate in the account of an entrepreneur's venture. This may require investigating different fields such as historiography, art history, the sciences, and techniques. As a consequence: "Another crucial step toward re-historicizing the field would require expanding the range of methodologies available to researchers." (Jones and Wadhwani, 2007: 358). Many concepts meet in the field of political economy, where institutional compromises are elaborated and where decisions need to rely on common knowledge. Therefore, we argue that referring to political economy in entrepreneurship corresponds to clarifying constructs. It is more about making some assumptions explicit rather than adding complex dimensions from alien disciplines. This is what both Schumpeter and Baxandall tried to do by using inference to determine the meaning of material facts and human choices, as we initially pointed out.

\subsection{Schumpeter's "Period Eye"}

Compared to contemporary versions of entrepreneurial ventures, Schumpeter's view of the entrepreneur's success tends to downplay several dimensions - in particular the many collective layers that contribute to Baxandall's "period eye" (and Schumpeter's zeitgeist). If today's scholar is surprised that Schumpeter appears to miss these dimensions, it may not have been so surprising in his time. Not only does he find them superfluous but treats them as obstacles. Two striking examples are nature and social dimensions. In the case of both Oberkampf and Knoll, we could argue that the story could be told as a pastoral (Holt, 2018) rather than as an epic because nature and natural materials are so important. In Schumpeter's view of the industrial revolution, dominating natural forces matters more than protecting natural resources. Many other case-studies illustrate that the beating heart of the group depends on such emotions as friendship (Farias, 2017), togetherness (Marti and Fernández, 
2015), and generosity (Holt and Popp, 2013). However, this is obscured by Schumpeter's focus on the leader, which he calls "the man of action".

We could add that a contemporary account would emphasize the role of local traditions, such as non-Western cultures and folk traditions (Subrahmanyan, 1990). Protestantism and Quakerism (Lapsansky and Verplank, 2001) play a crucial role in understanding both Oberkampf and Knoll, as they defend two different forms of eclecticism and syncretism. They involve strong aesthetic (Hjorth and Holt, 2016) and political commitments (Hjorth and Steyaert, 2010) as part of all their strategic choices. Why, then, would one deliberately negate all these forces and instead show the entrepreneur as the sole hero of the epic tale? This may have been the fashion of the time. This may be better understood through the best-sellers of the time: not only Marx's Das Kapital, but also works in the tradition of Herder, such as Spengler's The Decline of the West (Sternhell, 2009: 84). Further reinforcing this culture are the movies of S.M. Eisenstein and D.W. Griffith, and such artistic movements as futurism and vorticism which, according to Sternhell, Sznajder and Asher (1994: 238), both "made a frontal attack on decadence, academicism, frozen aestheticism, tepidity, and softness in general." . The question of who would have the last word became hotly debated. It is interesting to note that at one point, Schumpeter was concerned with this appeal and made his writing choices accordingly. Schumpeter's appeal to his audience was important to him. His writing style shows he liked to take risks and make provocations. He wanted to use style and zeitgeist in a skilful way so as to introduce new concepts. In many respects, entrepreneurship studies are full of promises made to please a contemporary audience. Many of them, far from being provocative, are based on a series of (supposedly) shared values, but this would deserve more explicit commitments as part of the debate.

\section{3."Tact" and the Reactionary Tradition}

In many respects, political economy makes Schumpeter's analysis quite distant from ours. It was also a reactionary vision in his own time, which is seldom mentioned. As Hirschman points out: "It may be true that: " Because of the stubbornly progressive temper of the modern era, "reactionaries" live in a hostile world." (Hirschman, 2013: 296).

Schumpeter wrote thinking the world was on the verge of collapse: 
Marx was wrong in his diagnosis of the manner in which capitalist society would break down; he was not wrong in the prediction that it would break down eventually. (Schumpeter, 1950, 456).

He clearly devised his theory of entrepreneurship as an alternative to modern democratic society. To him, as a "winner takes all" figure driven by his vision, energy and ambition, only the entrepreneur could truly enjoy full freedom of action.

(H)is unsteady commitment to freedom as a component of democracy was matched, as discussed above, by a fervent denial that democracy entailed universal suffrage or that it ruled out the conscious exclusion of the propertyless or disfavoured groups from voting rights, an argument that Schumpeter conceded would seriously undermine democracy's ties to "liberty". ([1942] 1976, 243-244).

This was not at all an abstract matter for Schumpeter, since he listed concrete examples of those who could be excluded from democracy:

Women, "Orientals", "Jews", and "Negroes" (244, 244 n. 12) (...) Schumpeter even strengthened (argued) that exclusions from suffrage on the basis of beliefs would be perfectly consistent with the type of elite democracy he envisioned (...). (Medearis, 2001: 126)

The same author argues that " $\mathrm{H}($ is) startlingly negative assumptions about human nature in politics" explain why:

In the last years of his life, just after the defeat of Nazi Germany, Schumpeter expressed sympathy for a kind of corporatist political and economic program that had become a part of Austrian fascism in the 1920s and 1930s (Schumpeter 1946 [1991], 401-405). (Medearis, 2001: 76).

Why are these conclusions so seldom mentioned when the Schumpeterian entrepreneur is so present in entrepreneurship scholarship? In a (theoretically) diverse culture of entrepreneurship today, what are the exclusions we fail to perceive when we present the entrepreneur as the "winner take all" and downplay the role of both the organization and the 
environment around him or her? We should constantly strive to detect such distortions that do a great injustice to the result of collective efforts.

To this end, we refer to two notions in Baxandall's aesthetics: tact and moral urgency.

Apparently antithetical as they seem, (they) should not be understood as opposed to one another but as two aspects of the same fundamental principle, two sides of the same coin: an expression of human sensitivity, tact is a sign of alertness to the dynamic of human concerns that ground and motivate our interest in art in the first place, and is thus a direct expression of what is most pressingly at stake in it. (Williams, 2017: 4)

Entrepreneurship has been officially a field in scholarly research for a long time now. We need to know more about its founding fathers and discuss their views in terms of political economy choices.

\subsection{Restraint and the "Ricardian Vice"}

Because Schumpeter regarded entrepreneurship as part of a more general system - i.e., economy as a source of prosperity - he asked questions that demand our attention when we write about entrepreneurship in relation to its social and political legitimacy. In many respects, Schumpeter refrained from addressing the "Ricardian vice" - even removing from his work chapters that he feared would be popular but too speculative in nature. He did not want to sacrifice the relationship between facts and concepts. A biography illustrates his tension:

He eliminated Chapter 7 not because he found it incorrect, but because as he noted, 'a fragment of the sociology of culture' was preferred by readers to 'the problems of dull economic theory' (2nd German ed., xi) and became an obstacle to a discussion of the latter problems (...). In fact, Chapter 7 is not 'a fragment of the sociology of culture'; it is a research program for a universal social science, (...). (Shionoya, 2005: 120-121).

To Schumpeter, the establishment of facts requires more than "impressionist theories" (Ibidem: 159), as they: 
... might teach us a lot about such fundamental problems as the nature of the class structure of capitalist society; the sort of class civilization which it develops and which differs so characteristically from the class civilization of feudal society; its schema of values; its politics, especially its attitudes to state and church and war; its performance and failures; its degree of durability. (Schumpeter, 1947: 158).

Therefore, Schumpeter's work offers a rare insight into the relationship between entrepreneurship and society - one that should be considered for all types of organizations (Stern and Barley, 1996), yet still fails to attract as much attention as it should nowadays.

Some of Schumpeter's views on society deserve to be pursued in entrepreneurship because of - not despite - their political economic dimensions. In relation to the cases we have been describing - and Schumpeter's 1947 analysis of the social gains of entrepreneurship for society in general (The Creative Response in Economic History ) - we ask three questions that are present in the text and should be addressed today. First, Oberkampf and Knoll represent two entrepreneurs who are celebrated for their achievement, not because of the disruption they initially caused. Schumpeter identifies entrepreneurial ventures with "the art of the weak" (Hjorth, 2012):

It should be observed at once that the "new thing" need not be spectacular or of historic importance. It need not be Bessemer steel or the explosion motor. It can be the Deerfoot sausage. To see the phenomenon even in the humblest levels of the business world is quite essential though it may be difficult to find the humble entrepreneurs historically. (Schumpeter, 1947: 151).

Yet surprisingly little is said about the transformation of the weak into the strong, and the weak entrepreneur.

Another issue is value creation. Schumpeter asks for more historical analysis to determine what value is generated and destroyed in society by booms and depressions (Ibidem: 157). $\mathrm{He}$ is specifically interested in the nature of the actual destruction. For instance, the destruction of social environments and natural resources is seldom mentioned in relation to the industrial revolution. In an age where sustainable development is a reference for many choices, there is little information on how similar choices were made in past ages, when sustainability was not an issue. 
Finally, Schumpeter balances the cost of the destruction and rebuilding with the next period, when the entrepreneur and his family begin to reap the benefits of both a guaranteed prophet and a monopoly. He also expresses a desire for further data that would allow him to measure the social gain; namely, the legal defence of licences and patents. Because Oberkampf's heirs failed to defend their patterns against large, low-cost industrialists, their company went bankrupt. Knoll Inc. communicates in its annual reports and custody declaration about the value of its 78 trademark registrations in the US and 226 trademarks registered in foreign countries (SEC declaration, 2013: 12). This question is critical today since many entrepreneurs succeed by submitting their invention and obtaining a patent. This is seldom presented as anything more than "playing by the rules" in contemporary entrepreneurship studies. However, Schumpeter clearly presented it as a problem, wondering how these patented inventions should be accounted for in the appraisal of social gains as they block new entrepreneurs and creative destruction. Blaug (2005: 72) points out that the question of intellectual property rights (IPR) was not so essential in the 1950s, the time of Schumpeter's last writings. Labels, patents, copyrights and trademarks were not tied together until the 1970s and 1980s as a consequence of economists' new theories on property rights economics.. Schumpeter associated endogenic growth with a healthy capitalism; and measuring such growth today requires us to look back at questions that his theories likely inspired although he was no longer around to witness their influence on capitalism in a post-industrial age.

\section{Conclusion}

Schumpeter's entrepreneur is quite famous; but he might be a victim of his success, as he ${ }^{2}$ remains largely misunderstood. It is a historical figure, in a historically-situated research. The goal of this paper was to uncover Schumpeter's choices in terms of political economy, in relation to his particular time period, possibly the spirit of the time, the "period's eye." Although Schumpeter remains highly popular, as his ideas have come to evolve some 70 years after his death, it's important to retain the original "patterns of intention" of his work in entrepreneurship studies in order to use concepts accurately. This is why we insist on "rehistoricizing" entrepreneurship studies (Wadhwani and Jones, 2014; Bucheli and Wadhwani, 2013) in Schumpeter's tradition.

\footnotetext{
${ }^{2}$ As we have seen, Schumpeter did not believe women could or should play that role.
} 
Although our use of Schumpeter's frame of analysis on the cases of Oberkampf and Knoll is only a preliminary step in uncovering the different sides of his political economy in relation to entrepreneurship and capitalism, this paper can already elaborate on two important findings. First, Schumpeter's method - historical materialism -remains highly effective, although history is too seldom used in entrepreneurship studies. Second, in many respects, Schumpeter's view of the role of the entrepreneur relates to conservative opinions about the central role of an elite; the legitimacy of social violence; and the risks of democratic values such as freedom and equality. We can safely say that such opinions would not be widely shared today among entrepreneurship scholars. If such is the case, this should prompt us to reengage debates on the legitimacy of entrepreneurial disruption and the destructive dimensions of creative destruction as Schumpeter did in his age. For instance, in many respects, contemporary historiography shuns one-sided, deterministic interpretation and attempts to reconcile multiple levels, as opposed to referring to social Darwinism as both Marx and Schumpeter did in their time. Other dimensions - such as different cultures and the use of natural resources in a post-industrial age - tend to play a significantly larger role than in the past. This transformation in the implicit values of entrepreneurship studies deserve more attention, as it influences our assumptions to a great extent.

Finally, because such assumptions can hardly be made explicit without a public debate including silenced controversies, we believe the strategic choice of case-studies describing a broader variety of entrepreneurs and including the destructive side of their ventures is essential to paving new avenues for research. For instance, Schumpeter deliberately chose to praise Richard Arkwright for his entrepreneurial success, whereas Marx had described him as a ruthless capitalist ${ }^{3}$. In that regard, it should come as a surprise that Schumpeter and his entrepreneur both stand as such ecumenical figures today. Schumpeter, for once, was not afraid of provocation (Hjorth, 2011) and we might be well inspired to welcome his most provocative questions today. For instance, in his 1947 essay, The Creative Response in Economic History, he raised the issues of the transformation from entrepreneur to businessman and the associated change in function, as well as inheritance in family business via property rights: "It was for the historian to establish or to refute" that there was "less scope for personal leadership."” (1947: 157). Seeking more historical facts, he points at a

\footnotetext{
3 ««« «Whoever knows the life history of Arkwright, will never dub this barber-genius noble. Of all the great inventors of the 18th century, he was incontestably the greatest thiever of other people's inventions and the meanest fellow.»« (Marx, 1887: 370, n 107).
} 
paradox: he is afraid entrepreneurs might be praised after the fact more for their personal success as capitalists within their enclosure than for what they had really achieved, as revolutionary forces disrupting dominating forces in a given social order. We believe this debate is central in the cases of both Oberkampf and Knoll, as well as most other entrepreneurs; and different political opinions would explain divergent value judgements on this paradox. Taking a stand in terms of political economy is essential to determine the role of entrepreneurs, their legacy and their contribution to society in general.

\section{Disclosure Statement}

No potential conflict of interest was reported by the authors.

\section{References}

Ades, D. (1995). Art and power: Europe under the dictators 1930-45 (Vol. 23). Hayward Gallery.

Aldrich, H.E. (2010). Entrepreneurship In Smelser P., \& Swedberg, R. (Eds.). The handbook of economic sociology, Princeton University Press, Princeton, pp 451-477

Allen J. (2002), The Romance of Commerce and Culture: Capitalism, Modernism, and the Chicago-Aspen Crusade for Cultural Reform, rev. ed.: University Press of Colorado, Boulder Allen R.L. (1991), Opening Doors: The Life \& Work of Joseph Schumpeter, Transaction, New Brunswick

Andersen, E. S. (2013). Evolutionary economics: post-Schumpeterian contributions. Routledge Publishing, London.

Ankersmit, F. R. (1996). Aesthetic politics: political philosophy beyond fact and value.

Stanford University Press, Stanford

Ankersmit, F. R. (1995). Historicism: an attempt at synthesis. History and Theory, In Ankersmit F.R. and Kellner K., A New Philosophy of History, Reaktion Books, London, 143161.

Ankersmit, F. R. (1983). Narrative logic: A semantic analysis of the historian's language (Vol. 7). The Hague: Nijhoff. 
Anteby, M. (2013). Manufacturing morals: The values of silence in business school education. University of Chicago Press.

Aspers, P., \& Godart, F. (2013). Sociology of fashion: Order and change. Annual Review of Sociology, 39, 171-192.

Aussel A. and Barjouet C. (2009), Etude des styles de mobilier, Encyclopédie Dunod, Paris

Backhaus, U. (2003). Entrepreneurship, Style and Vision (European Heritage in Economics and the Social Sciences, Volume 1)., Kluwer Academic Publishers.

Baumol, W. J. (1968). Entrepreneurship in economic theory. The American economic review, 64-71.

Baumol, W. J. (1996). Entrepreneurship: Productive, unproductive, and destructive. Journal of business venturing, 11(1), 3-22.

Baxandall M. (1988), Painting and experience in Fifteenth Century Italy: a primer in the Social History of Pictorial Eye. Oxford University press, Oxford

Baxandall, M. (1985), Patterns of intention, On the Historical Explanation of Pictures, Yale University Press, Yale

Becker, M., Knudsen, T., \& Swedberg, R. (2011). The Entrepreneur-Classic texts by Joseph A. Schumpeter. Stanford University Press.

Blaug, Mark, Why Did Schumpeter Neglect Intellectual Property Rights?. Review of Economic Research on Copyright Issues, 2005, 2(1), 69-74. Available at

SSRN: https://ssrn.com/abstract=1144888

Boutillier, S., \& Uzunidis, D. (2014). L'empreinte historique de la théorie de l'entrepreneur. Enseignements tirés des analyses de Jean-Baptiste Say et de Joseph Aloïs Schumpeter. Innovations, (3), 97-119.

Braudel F. 1992. Civilization and Capitalism, 15th-18th Century. Vol. I: The Structure of Everyday Life, University of California Press, Berkeley

Bucheli, M., \& Wadhwani, R. D. (Eds.). (2014). Organizations in time: History, theory, methods. Oxford University Press, Oxford

Campbell J. (1978), The German Werkbund: The Politics of Reform in the Applied Arts, Princeton University Press, Princeton

Cantwell, J. (2002). Innovation, profits, and growth: Penrose and Schumpeter. In Penrose, E. T. (2002). The growth of the firm: the legacy of Edith Penrose. Oxford University Press, pp 215-248.

Casson, M., \& Godley, A. (2005). Entrepreneurship and Historical Explanation. In Y. Cassis and I.P. Minoglou (Eds.), Entrepreneurship in theory and history, pp. 25-60. Basingstoke: 
Palgrave Macmillan.

Castillo G. (2005), Domesticating the Cold War: Household Consumption as Propaganda in Marshall Plan Germany, Journal of Contemporary History 40.2, 261-288.

Castillo G. (2010), Cold War on the Home Front: The Soft Power of Midcentury Design, University of Minnesota Press, Minneapolis

Chandler, A. D. (1962). Strategy and structure: Chapters in the American industrial enterprise. MIT press, Boston

Chapman S.D. and S. Chassagne (1981), European Textile Printers in the Eighteenth Century: A Study of Peel and Oberkampf, London.

Chassage S. (1980), Obekampf un grand patron au siècle des Lumières, l'inventeur de la toile de Jouy, Editions Aubier, Paris

Chassagne S. (1980), Oberkampf un entrepreneur capitaliste au siècle des Lumières, Aubier, Paris

Chassagne S. (1981), Une femme d'affaires au XVIII siècle, la correspondance de Madame de Maraise, collaboratrice d'Oberkampf, Privat, Paris

Chassagne S. (1981), Une femme d'affaires au XVIIIème Siècle, Editions Privat, Paris

Chassagne S., Dewerpe A. and Yves Gaulupeau (1976), Les ouvriers de la manufacture de toiles imprimées d’Oberkampf à Jouy-en-Josas (1760-1815), dans Mouvement social, n97, octobre-décembre

Chia, R. C., \& Holt, R. (2009). Strategy without design: The silent efficacy of indirect action. Cambridge University Press.

Chia, Robert and Holt, R. (2009), Strategy without Design: The Silent Efficacy of Indirect Action, Cambridge University Press. Cambridge

Clarke, J., \& Holt, R. (2010). The mature entrepreneur: A narrative approach to entrepreneurial goals. Journal of Management Inquiry, 19(1), 69-83.

Cohen, Y. (2013), Le siècle des chefs. Une histoire transnationale du commandement et de l'autorité (1890-1940). Editions Amsterdam, Paris.

Croce, B. (2017 (1913)). Aesthetic: As science of expression and general linguistic.

Routledge, London

Dawson, A., \& Hjorth, D. (2012). Advancing family business research through narrative analysis. Family Business Review, 25(3), 339-355.

Deutsche, R. (1996). Evictions: Art and spatial politics (p. 400). MIT Press, Cambridge

Dewerpe A. et Galupeau Y., La fabrique des prolétaires, presses de l'ENS, Paris 
Dewerpe, A. and Gaulupeau Y. (1990), La fabrique des prolétaires, les ouvriers de la manufacture Oberkampf à Jouy-en-Josas (1760-1815), Presse de l'Ecole Normale Supérieure, Paris.

Dockès, P. (2015). Les débats sur la stagnation séculaire dans les années 1937-1950. Revue économique, 66(5), 967-992.

Dockès, P., \& Rosier, B. (1991). Histoire 'raisonnée’ et économie historique. Revue économique, 181-208.

Farias, C. (2017). That's What Friends Are For: Hospitality and affective bonds fostering collective empowerment in an intentional community. Organization Studies, 38(5), 577-595.

Flaschel, P. (2009). Macrodynamics of Capitalism-Synthesis of Marx, Keynes and Schumpeter. Springer Science \& Business Media, London

Fligstein, N., \& McAdam, D. (2012). A theory of fields. Oxford University Press.

Floré, F. (2012), Architect-designed interiors for a culturally progressive upper-middle class: the implicit political presence of Knoll International in Belgium, Atomic dwelling. anxiety, domesticity, and postwar architecture. Routledge, London, p 169-185

Floré, F., \& McAtee, C. (Eds.). (2017). The Politics of Furniture: Identity, Diplomacy and Persuasion in Post-War Interiors. Taylor \& Francis.

Freeman, C., \& Louçã, F. (2001). As time goes by: from the industrial revolutions to the information revolution. Oxford University Press.

Gartner, W. B. (1985). A conceptual framework for describing the phenomenon of new venture creation. Academy of management review, 10(4), 696-706.

Gartner, W. B. (1988). "Who is an entrepreneur?" is the wrong question. American journal of small business, 12(4), 11-32.

Genter, R. (2010), Late Modernism, Art, Culture and Politics in Cold War America, University of Pennsylvania Press, Philadelphia

Goody J. (1977), The Domestication of the Savage Mind, Cambridge University Press, Cambridge.

Gril-Mariotte, A. (2009).,Topical Themes from the Oberkampf Textile Manufactory, Jouy-enJosas, France, 1760-1821. Studies in the Decorative Arts, 17(1), 162-197.

Gril-Mariotte, A. (2015). Les toiles de Jouy: histoire d'un art décoratif: 1760-1821. Presses

Gril-Mariotte, A. (2015). Les toiles de Jouy. Presses universitaires de Rennes, Rennes

Halbwachs, M. (1992). On collective memory. University of Chicago Press, Chicago

Harris, J. (1995). Federal art and national culture: The politics of identity in New Deal America, Cambridge University Press, Cambridge 
Heilbroner R.L. (1993), “Was Schumpeter Right after all?” Journal of Economic Perspectives 7, pp. 87-96

Helin, J., Hernes, T., Hjorth, D., \& Holt, R. (Eds.). (2014). The Oxford handbook of process philosophy and organization studies. Oxford University Press.

Hirschman, Albert O. (2013), The Essential Hirschman. Princeton University Press. Princeton Hjorth, D. (2003), Rewriting Entrepreneurship - For a New Perspective on Organisational Creativity. Copenhagen/Malmö/Oslo: CBS Press/Liber/Abstrakt.

Hjorth, D. (2011). On provocation, education and entrepreneurship. Entrepreneurship and Regional Development, 23(1-2), 49-63.

Hjorth, D. (2012). Organisational entrepreneurship - An art of the weak? In D. Hjorth (Ed.), Handbook of organizational entrepreneurship (pp. 169-192). Cheltenham, UK: Edward Elgar.

Hjorth, D., \& Steyaert, C. (2004). Narrative and discursive approaches in entrepreneurship: a second movements in entrepreneurship book. Edward Elgar publishing, London Hjorth, D., \& Steyaert, C. (2009). Entrepreneurship as disruptive event. The Politics and Aesthetics of Entrepreneurship: A Fourth Movements of Entrepreneurship Book, Edward Elgar publishing, London

Hjorth, D., \& Steyaert, C. (Eds.). (2010). The politics and aesthetics of entrepreneurship: A fourth movements in entrepreneurship book. Edward Elgar publishing, London

Hjorth, D., and R. Holt. (2016), "It's Entrepreneurship, Not Enterprise: Ai Weiwei as Entrepreneur.” Journal of Business Venturing Insights 5: 50-54.

Hofstadter R. (1948). The American Political Tradition: And the Men Who Made it. Knopf Publishing, New York.

Hofstra, P.G. (2008), Florence Knoll. Design and the American Office Workplace, Dissertation Thesis, University of Kansas

Holt, R. (2018), Judgment and Strategy, Oxford University Press. Oxford

Holt, R., \& Popp, A. (2013). Emotion, succession, and the family firm: Josiah Wedgwood \& Sons. Business History, 55(6), 892-909.

James K. (2006), Bauhaus Culture: From Weimar to the Cold War, University of Minnesota Press, Minneapolis

Kapp K.W. (1978), The social costs of business enterprise, Spokesman Books, New York Kentgens-Craig M. (1999), The Bauhaus and America: First Contacts, 1919-1936, MIT Press, Cambridge 
Lapsansky E.J. and Verplanck A.A. (2001), eds. Quaker Aesthetics: Reflections on a Quaker Ethic in American Design and Consumption. University of Pennsylvania Press, Philadelphia Larrabee, E. (1981), Knoll Design. Harry N. Abrams, Inc., New York.

Larrabee, E. and Vignelli M. (1990, Knoll Design. New York: Harry N. Abrams, 1990.

Lettres patentes sur arrêt du conseil du 20 mai 1783, en faveur des sieurs Oberkampf et Sarrasin de Maraise, entrepreneurs-propriétaires de la Manufacture Royale de Toile, MFICHE F-23630 (426), L 1.15-MF2-4998

Lippmann, S. and Aldrich, H.E. (2014). History and Evolutionary Theory. In M. Bucheli \& R.D. Wadhwani (Eds.) Organizations in Time: History, Theory, Methods, pp. 192-216. Oxford: Oxford University Press.

Lutz, B. (2010), Knoll : That which Endures, Rizzoli, Milano

Lutz, B. (2010). Knoll: A modernist universe. Rizzoli International Publications, New York. Maclean, M., Harvey, C., \& Clegg, S. R. (2016). Conceptualizing historical organization studies. Academy of Management Review, 41(4), 609-632

Margolin, V. (1989), Design Discourse, Chicago: The University of Chicago Press, Chicago Margolin, V. (1995), The Idea of Design, Cambridge: The MIT Press, Boston

Martí, I., \& Fernández, P. (2015). Entrepreneurship, togetherness, and emotions: A look at (Postcrisis?) Spain. Journal of Management Inquiry, 24(4), 424-428.

Marx, K. (1965). Capital: A critical analysis of Capitalistic Production (Vol. 3). Progress Publishers.

Marx, K. (2008 (1846)), The poverty of philosophy, Cosimo Inc., New York.

Marx, K., \& Engels, F. (1980 (1867)). Marx \& Engels Collected Works Vol 13: Marx and Engels: 1854-1855. Lawrence \& Wishart.

McCraw T.K. (2007), Prophet of Innovation. Joseph Schumpeter and Creative Destruction, Harvard University Press, Cambridge

McDonald G. (2004), "Selling the American Dream: MoMA, Industrial Design and Post-War France", Journal of Design History 17.4., 397-412

Medearis, J. (2001). Joseph Schumpeter's Two Theories of Democracy, Harvard University Press, Harvard

Morris, M. (2000). Why Schumpeter Was Wrong to Deny Citizens Participation in the Political Decision-Making Process. UCL Jurisprudence Rev., 80.

Nietzsche, F. (1998 (1888)). Twilight of the Idols. Oxford Paperbacks, Oxford.

North D.C., Wallis J.J., and Weingast B.R. (2009), Violence and Social Orders, Cambridge University Press, Oxford. 
Penrose, E. (2009 (1959)). The theory of the growth of the firm/Edith Penrose; with a new introduction by Christos N. Pitelis. Oxford University Press, Oxford

Perroux, F. (1965), La pensée économique de Joseph Schumpeter. Les dynamiques du capitalisme, Librairie Droz, Genève

Petitcol X. (1993), Découverte de toiles d'Oberkampf et de papiers peints de Réveillon à décor assorti dans Bulletin du CIETA, n²71, p.105-111

Popp, A., \& Holt, R. (2013). Entrepreneurship and being: the case of the Shaws. Entrepreneurship \& Regional Development, 25(1-2), 52-68.

Prendergast, R. (2005). Schumpeter, Hegel and the vision of development. Cambridge Journal of Economics, 30(2), 253-275.

Read, S., Sarasvathy, S., Dew, N., \& Wiltbank, R. (2016). Effectual entrepreneurship. Routledge.

Rousseau, J. J. (1974). Emile (1762). Trans. Barbara Foxley. Dent publishing, London.

Ruskin, J. (1903 (1854)), The Works of John Ruskin, edited by Edward T. Cook and Alexander Wedderburn, vol. V, London: George Allen,

Sarasvathy, S. D. (2003). Entrepreneurship as a science of the artificial. Journal of Economic Psychology, 24(2), 203-220.

Schuldenfrei, R. (Ed.). (2012). Atomic dwelling: anxiety, domesticity, and postwar architecture. Routledge, London.

Schumpeter, J. (1909). On the concept of social value. The quarterly journal of economics, 23(2), 213-232.

Schumpeter, J.A. (1934), The Theory of Economic Development, Harvard University Press, Cambridge.

Schumpeter, J.A. (1942), Capitalism, Socialism and Democracy, Harper \& Brothers, New York

Schumpeter, J. A. (1947). The creative response in economic history. The journal of economic history, 7(2), 149-159.

Schumpeter J.A. (1949), "The Communist Manifesto in Sociology and Economics”, Journal of Political Economy, pp. 199-212, in Richard V. Clemence (1951), ed., Schumpeter J.A., Essays on Entrepreneurs, Innovations, Business Cycles, and the Evolution of Capitalism, Addison-Wesley, Cambridge.

Schumpeter, J. A. (1980). Methodological individualism. Institutum Europaeum, Brussels. Schumpeter, J. A. (2006). History of economic analysis. Routledge, London 
Schumpeter, J. A. (2017). Essays: on entrepreneurs, innovations, business cycles and the evolution of capitalism. Routledge.

Schumpeter, J.A. (2003(1939)), Business Cycles: A Theoretical, Historical, and Statistical Analysis of the Capitalist Process, two vols., McGraw-Hill, New York.

Scranton P. (1977), Endless Novelty: Specialty Production and American Industrialization, 1865-1925, Princeton University Press, Princeton.

Sinoya Y. (2005): The Soul of the German Historical School. Methodological Essays on Schmoller, Weber and Schumpeter. New York: Springer

Smelser N.J. and Swedberg R. (2005), Introducing Economic Sociology, The Handbook of Economic Sociology, Cambridge University Press, Cambridge, pp 3-25.

Smelser N.J. and Swedberg R. (2010), The handbook of economic sociology, Princeton University Press, Princeton

Smith, A. (1776). An Inquiry into the Nature and Causes of the Wealth of Nations, 2 vols. $W$. Strahan and T. Cadell. [MTG].

Staniszewski, M. A. (1998). The power of display: A history of exhibition installations at the Museum of Modern Art (p. 160). MIT Press, Cambridge.

Stern, R. N., \& Barley, S. R. (1996). Organizations and social systems: Organization theory's neglected mandate. Administrative Science Quarterly, 146-162.

Sternhell, Z. (2009), The Anti-Enlightenment Tradition. Yale University Press, Yale.

Sternhell, Z., Sznajder M. and Asher M. (1994), The Birth of Fascist Ideology. From Cultural Rebellion to Political Revolution. Princeton University Press, Princeton

Stinchcombe, A. L. (1997). On the virtues of the old institutionalism. Annual review of sociology, 23(1), 1-18.

Stolper W.R. (1994), Joseph Alois Schumpeter: The Public Life of a Private Man, Princeton University Press, Princeton

Strauss, L. (1947). On the intention of Rousseau. Social Research, 455-487.

Strauss, L., \& Cropsey, J. (Eds.). (2012). History of political philosophy. University of Chicago Press.

Subrahmanyan, S. (1990), The Political Economy of Commerce: Southern India, 15001650: Cambridge University Press, Cambridge

Swedberg R. (1991), Schumpeter: A Biography. Princeton University Press, Princeton

Swedberg, R. (2006). Social entrepreneurship: the view of the young Schumpeter. In Steyaert, C., \& Hjorth, D. (Eds.). Entrepreneurship as social change: A third new movements in entrepreneurship book (Vol. 3). Edward Elgar Publishing., p. 21-34. 
Thorpe, R., \& Holt, R. (Eds.). (2007). The Sage dictionary of qualitative management research. Sage.

Tigerman, B. (2007), “I am Not a Decorator’: Florence Knoll, the Knoll Planning Unit and the Making of the Modern Office", Journal of Design History 20.1.61-74.

Veblen, T. (1994), Collected Works of Thorsten Veblen: The Place of Science in Modern Civilisation, Routledge, London

Vérin, H. (1982). Entrepreneurs, entreprise: histoire d'une idée (Vol. 2). Presses universitaires de France.

Wadhwani, R. D. (2010). 15. Historical reasoning and the development of entrepreneurship theory. Historical Foundations of Entrepreneurial Research, 343-380 in Landström, H., \& Lohrke, F. (Eds.). (2010). Historical foundations of entrepreneurial research. Edward Elgar Publishing.

Wadhwani, R. D., \& Jones, G. (2014). Schumpeter's plea: Historical reasoning in entrepreneurship theory and research. Organizations in time: History, theory, methods, 192216.

Williams, R. (2017). Michael Baxandall, Vision and the Work of Words. Routledge, London. 
Tables and Figures

\begin{tabular}{|c|c|c|}
\hline & Tribute paid & Nuances, differences in positions combinations \\
\hline $\begin{array}{l}\text { Resource- } \\
\text { based view }\end{array}$ & $\begin{array}{l}\text { Penrose, (2009: 74) mentions Schumpeter } \\
\text { when a new market is created (invented from } \\
\text { scratch). } \\
\text { The rest of the time, she follows his historical } \\
\text { method to identify the reasons for succcess. } \\
\text { Innovation is key since the firm's response to } \\
\text { creative destruction is R\&D and innovation; to } \\
\text { face the threat of competition (Penrose, } 2009 \text { : } \\
\text { 99) the firm needs to commit resources to } \\
\text { learning. When Schumpeter focuses more on } \\
\text { « big ideas » (causing «perennial gales) and } \\
\text { Penrose organizational learning (discrete } \\
\text { rushes). }\end{array}$ & $\begin{array}{l}\text { «The Schumpeterian 'entrepreneur', though more } \\
\text { colourful and identifiable, is too dramatic a person for } \\
\text { our purposes. Schumpeter was interested in economic } \\
\text { development and his entrepreneur was an innovator } \\
\text { from the point of view of the economy as a whole; we } \\
\text { are interested in the growth of firms, and here the } \\
\text { entrepreneur is an innovator from the point of view of } \\
\text { the firm, not necessarily from the point of view of the } \\
\text { economy as a whole.» (Penrose, } 2009: 33 \text { no 35). }\end{array}$ \\
\hline Institutionalism & $\begin{array}{l}\text { Baumol (1996) adopts an institutionalist } \\
\text { approach although he praises Schumpeter's } \\
\text { contribution to the theory of the firm via his } \\
\text { evocation of the figure of the entrepreneur : } \\
\text { «Only Schumpeter (... ) succeeded in infusing } \\
\text { him with life and in assigning to him a specific } \\
\text { area of activity to any extent commensurate } \\
\text { with his acknowledged importance.» (Baumol, } \\
\text { 1968: 64). To Baumol, Schumpeter' } \\
\text { contribution is essentially related to the micro- } \\
\text { level theorization of the field. }\end{array}$ & $\begin{array}{l}\text { Looking for a theory of institutional change (at field } \\
\text { level) the new instititutionalism approach of the } \\
\text { entrepreneur (Smelser and Swedberg, 2010: 51) } \\
\text { insists on structural change. }\end{array}$ \\
\hline $\begin{array}{l}\text { Population } \\
\text { ecology }\end{array}$ & $\begin{array}{l}\text { As one of the fathers of institutionalism, he } \\
\text { asked pioneering questions about the forms of } \\
\text { institutions that make the competitive structure } \\
\text { of capitalism possible, among them «the role } \\
\text { of competing political elites » since «In } \\
\text { Schumpeter's argument the ruling institutions } \\
\text { affected organizational ecology, and in } \\
\text { particular what he called "creative destruction" } \\
\text { (Schumpeter (1964 [1939]), 1942) (...)» as } \\
\text { «biological evolution has powerful analogies to } \\
\text { Schumpeter's reasoning» (Stinchcombe, 1997: } \\
\text { 13). }\end{array}$ & $\begin{array}{l}\text { Stinchcombe prefers to focus on population ecology } \\
\text { and new industries; looking for a theory of } \\
\text { institutional change (at field level) the new } \\
\text { instititutionalism approach of the entrepreneur } \\
\text { (Smelser and Swedberg, } 2010: 51 \text { ) }\end{array}$ \\
\hline Effectuation & $\begin{array}{l}\text { The cognitive style of the nascent entrepreneur, } \\
\text { a key factor in making choices and in the } \\
\text { creation of legitimacy. It claims : «(..) a } \\
\text { behavioural perspective has much in common } \\
\text { with the Austrian-school analysis and the } \\
\text { intellectual tradition of Schumpeter (1934) and } \\
\text { Hayek (1945).» (Read, Sarasvathy, Dew, and } \\
\text { Wiltbank, 2016: 95). In particular, imagination } \\
\text { and daring are key to the creation of new } \\
\text { markets: «In the spirit of Schumpeter (1934), « } \\
\text { (...) the effectual premise (is) that many } \\
\text { opportunities can be created, rather than } \\
\text { discovered and new markets can often be } \\
\text { viewed as a residual, explored via creative and } \\
\text { transformative tactics.» (Ibidem) }\end{array}$ & $\begin{array}{l}\text { The more recent theory of effectuation also attributes } \\
\text { to Schumpeter that micro-level by focusing on «(...) } \\
\text { marketers and entrepreneurs do succeed in their efforts } \\
\text { to shape the preferences and tastes of their customers. } \\
\text { As early as } 1939 \text {, Schumpeter pointed out, «It was not } \\
\text { enough to produce satisfactory soap, it was also } \\
\text { necessary to induce people to wash" (Schumpeter, } \\
1939, \text { p. } 243) \text { ). (Saraswathy, } 2003: 97) \text {. } \\
\text { Yet effectuation tends to sport a different approach to } \\
\text { entrepreneurial success than Schumpeter, in that it } \\
\text { would not support Schumpeter's elitism: } \\
\text { «[l] eadership [...] does not consist simply in finding } \\
\text { or creating the new thing but in so impressing the } \\
\text { social group with it as to draw it on in its wake." } \\
\text { (Schumpeter, 1934: 88). }\end{array}$ \\
\hline $\begin{array}{l}\text { Narrative } \\
\text { approaches }\end{array}$ & $\begin{array}{l}\text { Gartner mentions Schumpeter (1934) in } 5 \text { out } \\
\text { of } 6 \text { of the processes involved in entrepreneurial } \\
\text { ventures: «The entrepreneur locates a business } \\
\text { opportunity; The entrepreneur accumulates } \\
\text { resources; The entrepreneur markets products } \\
\text { and services; The entrepreneur produces the } \\
\text { product; The entrepreneur builds an } \\
\text { organization. " (Gartner, 1985: 699-700) }\end{array}$ & $\begin{array}{l}\text { Gartner argues «Schumpeter did not mention The } \\
\text { entrepreneur responds to government and society » } \\
(1985: 700) \text {, the sixth point. Yet there is a great } \\
\text { interest for Schumpeter's view of the social context } \\
\text { among socio-economists as: «No one is an } \\
\text { entrepreneur forever, when he or she is actually doing } \\
\text { the innovative activity. » (Swedberg, 2000: 18). }\end{array}$ \\
\hline
\end{tabular}

Table 1. Schumpeter's influence on Entrepreneurship Theories 


\begin{tabular}{|c|c|c|c|}
\hline $\begin{array}{l}\text { Theories of } \\
\text { change }\end{array}$ & Schumpeterian positions & Schumpeter & $\begin{array}{l}\text { Exegesis of Schumpeter's positions } \\
\text { in each discipline }\end{array}$ \\
\hline $\begin{array}{l}\text { Socio- } \\
\text { Economics: } \\
\text { nature of } \\
\text { economic } \\
\text { forces }\end{array}$ & $\begin{array}{l}\text { Individual forces, } \\
\text { irregular although part } \\
\text { of a stable system of } \\
\text { endogeneic change (no } \\
\text { "deus ex machina") }\end{array}$ & $\begin{array}{l}\text { «(..) creative response-the } \\
\text { frequency of its occurrence in a group, } \\
\text { its intensity and success or failure- } \\
\text { has obviously something, be that much } \\
\text { or little, to do (a) with quality of the } \\
\text { personnel available in a society, (b) } \\
\text { with relative quality of personnel, that } \\
\text { is, with quality available to a particular } \\
\text { field of activity relative to quality } \\
\text { available, at the same time, to others, } \\
\text { and (c) with individual decisions, } \\
\text { actions, and patterns of behavior. } \\
\text { Accordingly, a study of creative } \\
\text { response in business becomes } \\
\text { coterminous with a study of } \\
\text { entrepreneurship. The mechanisms of } \\
\text { economic change in capitalist society } \\
\text { pivot on entre- preneurial activity.» } \\
\text { (Schumpeter, 1947: 150). }\end{array}$ & $\begin{array}{l}\text { The pivot role of the individual: «the } \\
\text { bearer of the mechanism of change } \\
\text { (...) significantly more in line with } \\
\text { the Hegelian concept of the leader as } \\
\text { the instrument of change in his } \\
\text { society." (Prendergast, 2006: 266). } \\
\text { «(..) the idea (...) that reality, as we } \\
\text { know it from experience, may be in } \\
\text { itself an evolutionary process, } \\
\text { evolving from inherent necessity, } \\
\text { instead of being a set of phenomena } \\
\text { that seek a definite state or level, so } \\
\text { that an extraneous factor... is } \\
\text { necessary in order to move them to } \\
\text { another state or level" (...) } \\
\text { (Schumpeter's description of what } \\
\text { he termed 'Hegel's emanatist } \\
\text { conception of evolution.» } \\
\text { (Prendergast, 2006: } 253 \text { ). }\end{array}$ \\
\hline $\begin{array}{l}\text { Economics: } \\
\text { equilibrium } \\
\text { and } \\
\text { disequilibrium } \\
\text { combined in } \\
\text { irregular time } \\
\text { cycles (caused } \\
\text { by the } \\
\text { unpredictable } \\
\text { introduction } \\
\text { of } \\
\text { innovations) } \\
\text { in the form of } \\
\text { a dialectic } \\
\text { change }\end{array}$ & $\begin{array}{l}\text { Dynamism: «(...) what } \\
\text { causes economic } \\
\text { fluctuations may either } \\
\text { be individual shock } \\
\text { which impinge on the } \\
\text { system from outside, or } \\
\text { a distinct process of } \\
\text { change generated by the } \\
\text { system itself, but in both } \\
\text { cases the theory of } \\
\text { equilibrium supplies us } \\
\text { with the simplest code of } \\
\text { rules which the system } \\
\text { will response." } \\
\text { (Schumpeter, 1939: } 68) \text {. }\end{array}$ & $\begin{array}{l}\text { "Working somehow though } \\
\text { accumulation, somehow destroys the } \\
\text { economy as well as the society of } \\
\text { competitive capitalism and somehow } \\
\text { produces an untenable situation that } \\
\text { will somehow give birth to another } \\
\text { type of social organisation." } \\
\text { (Schumpeter, 1961: } 441 \text { ). Marx fails to } \\
\text { see that his view of the capitalist mode } \\
\text { of production as driven by one single } \\
\text { law (the tendency of the rate of profit } \\
\text { to fall) is a theoretical impasse since } \\
\text { capitalism has so far survived all its } \\
\text { cyclical crises, contrary to what Marx } \\
\text { predicted. This proves the capitalist } \\
\text { system is homeostatic enough to } \\
\text { constantly regain its equilibrium }\end{array}$ & $\begin{array}{l}\text { Schumpeter believes Marx ignored } \\
\text { the role of creative destruction: he } \\
\text { «failed to acknowledge the } \\
\text { contribution of men of superior } \\
\text { energy and intelligence" } \\
\text { (Prendergast, 2006: 254) and «First } \\
\text { the economy (is) defined as an } \\
\text { 'organic' whole, propelled by a } \\
\text { process of development with } \\
\text { mutations. Second, this defined a } \\
\text { non-mechanistic and historical view } \\
\text { of capitalism as one of creation and } \\
\text { destruction.» (Freeman and Louçã, } \\
\text { 2001: 50) }\end{array}$ \\
\hline $\begin{array}{l}\text { Historical } \\
\text { economics } \\
\text { (history of } \\
\text { thoughts and } \\
\text { ideas, } \\
\text { hermeneutics) }\end{array}$ & Evolutionism (Darwin) & $\begin{array}{l}\text { «The essential point to grasp is that } \\
\text { dealing with capitalism, we are } \\
\text { dealing with an evolutionary process." } \\
\text { (Schumpeter, } 1949 \text { : } \\
\text { «Development in our sense is a } \\
\text { distinct phenomenon, entirely foreign } \\
\text { to what may be observed in the } \\
\text { circular flow or in the tendency toward } \\
\text { equilibrium. It is spontaneous and } \\
\text { discontinuous change in the channels } \\
\text { of the flow, disturbance of } \\
\text { equilibrium, which forever alters and } \\
\text { displaces the equilibrium state } \\
\text { previously existing.»(Schumpeter, } \\
\text { [1911] 1934, 64). }\end{array}$ & $\begin{array}{l}\text { This evolution involves a form of } \\
\text { social violence (competition for } \\
\text { power) with a series of value } \\
\text { judgements which are referred to } \\
\text { Darwin although it may contradict } \\
\text { his views. Elimination by } \\
\text { substitution: «Just as businesses go } \\
\text { up and down, so too do } \\
\text { entrepreneurs and their families. } \\
\text { "This represents the most important } \\
\text { factor of rise in the social scale in the } \\
\text { capitalist world. Because it proceeds } \\
\text { by competitively destroying old } \\
\text { businesses and hence the existences } \\
\text { dependent upon them, there always } \\
\text { corresponds to it a process of } \\
\text { decline, of loss of caste, of } \\
\text { elimination. » (Mc Craw, 2007: 71). }\end{array}$ \\
\hline
\end{tabular}

Table 2. Schumpeter's Ideas and Their Echo in Political Economy, Economics and Economic History Today 


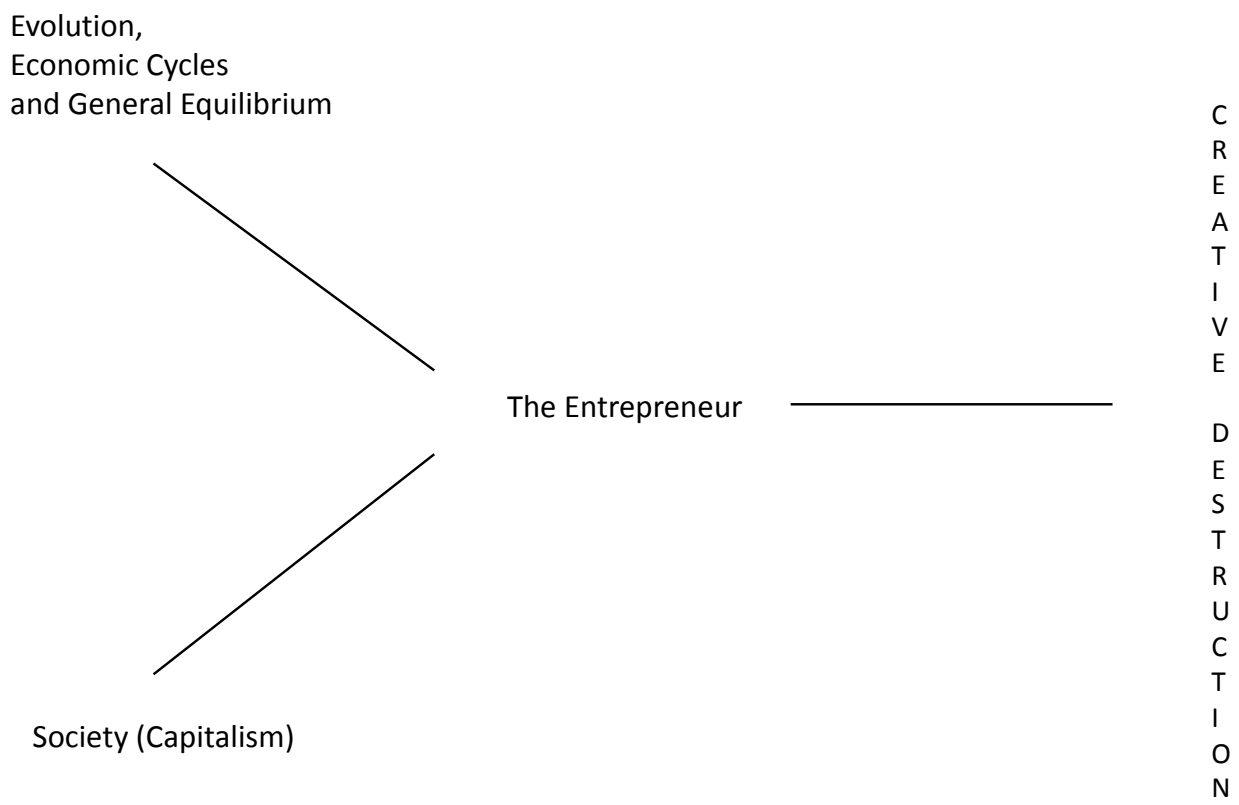

Figure 1. Schumpeter's Vision of Economic and Social Change

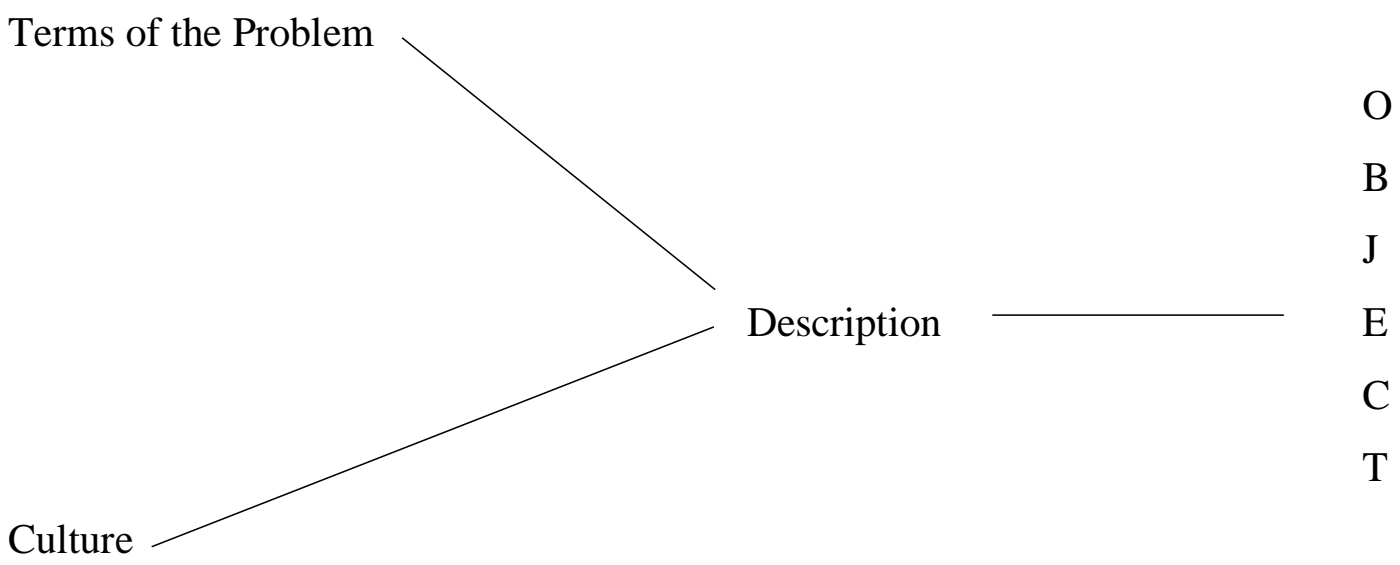

(From Baxandall, 1985: 67)

Figure 2. Baxandall's system of "patterns of intentions" (aesthetic invention) 


\begin{tabular}{|c|c|c|}
\hline Key issues & Problems & Solutions \\
\hline Elite & $\begin{array}{l}\text { Rent, accumulation, mediocrity } \\
\text { «Just as businesses go up and down, so too } \\
\text { do entrepreneurs and their families. "This } \\
\text { represents the most important factor of rise } \\
\text { in the social scale in the capitalist world. } \\
\text { Because it proceeds by competitively } \\
\text { destroying old businesses and hence the } \\
\text { existences dependent upon them, there } \\
\text { always corresponds to it a process of } \\
\text { decline, of loss of caste, of elimination. " } \\
\text { (Mc Craw, 2007: 71). } \\
\text { «Schumpeter maintained that there are a } \\
\text { limited number of people in various areas } \\
\text { of social life, who are able to destroy } \\
\text { existing orders through the introduction of } \\
\text { innovations and thereby succeed in } \\
\text { creating the current of the time (...).» } \\
\text { (Shinoya, 2005: 59). }\end{array}$ & $\begin{array}{l}\text { The entrepreneur: } \\
\text { «The entrepreneur is a leader of the economic order who acts } \\
\text { with a form of violence: "for Schumpeter "the type of man } \\
\text { defined as a "leader" overthrows the existing order and } \\
\text { creates a new direction.» (Shionoya 1997: 38). } \\
\text { «Industrial leaders must shoulder an often unreasonable } \\
\text { burden of current work, which takes up the greater part of } \\
\text { each day." Entrepreneurs need "extraordinary physical and } \\
\text { nervous energy.»(Schumpeter, 1927: } 123 \text { in McCraw, 2007: } \\
\text { 162). } \\
\text { Bourgeois alliance: «The first thing about the 'economics } \\
\text { proper' of the [Manifesto is that] Marx launched out on a } \\
\text { panegyric upon bourgeois achievement that has no equal in } \\
\text { economic literature.» (Schumpeter, 1949: 301). }\end{array}$ \\
\hline $\begin{array}{l}\text { Rule the world } \\
\text { and harness } \\
\text { the forces of } \\
\text { nature as well } \\
\text { as social } \\
\text { oppositions }\end{array}$ & $\begin{array}{l}\text { Need to destroy static obstacles to } \\
\text { progress. } \\
\text { Entrepreneurs belong to a small elite } \\
\text { group of visionaries whereas "The } \\
\text { disposition of the mass of people is } \\
\text { static and hedonistic", while "new } \\
\text { enterprises mean new dangers that } \\
\text { may cost you your existence.» } \\
\text { (Schumpeter, 1911: } 183 \text { ). } \\
\text { He faces many a hostile crowd, as } \\
\text { Schumpeter notes in Business Cycles: } \\
\text { "Workers resistance: And from 1811 to } \\
\text { 1816 the notorious Luddites hammered } \\
\text { textile machinery to bits. » (1939: 271- } \\
\text { 272). }\end{array}$ & $\begin{array}{l}\text { Creative destruction } \\
\text { Appropriation : «The principle is this: the entrepreneur buys } \\
\text { productive labour and thereby removes it from its ordinary } \\
\text { static use; he makes use of it without asking its owners for } \\
\text { permission; and in this way, he forces the economy into new } \\
\text { directions." (Schumpeter, 1911, p. 189). Schumpeter sums } \\
\text { up the argument in Chapter } 2 \text { of Theorie as follows: "Like } \\
\text { the carrying out of new combinations is the form and content } \\
\text { of development, the activity of the leader is the driving } \\
\text { form.» (Schumpeter, 2002, p. 434). } \\
\text { Investment bankers generate the cash flows, that is sustain } \\
\text { the dynamics by speculating. They create: "new purchasing } \\
\text { power out of nothing." The investment banker is not just a } \\
\text { middleman but "a producer" of money and credit, "the } \\
\text { capitalist par excellence." (1934: 70) all entrepreneurs } \\
\text { compete to attract. }\end{array}$ \\
\hline Decline & $\begin{array}{l}\text { «Mosca and Pareto, who insisted that } \\
\text { democracy could at best be a kind of } \\
\text { window dressing around elite rule, or a } \\
\text { kind of increase in the legality and } \\
\text { peacefulness of the methods of elite } \\
\text { domination (Mosca 1967, 50; Pareto 1966, } \\
\text { 270). The elite theorists' } \\
\text { reconceptualization made democracy not } \\
\text { just potentially controllable by elites but } \\
\text { actually intrinsically, necessarily so } \\
\text { dominated.» (Medearis, 2001: 8). } \\
\text { A new problem occurs with the new age of } \\
\text { capitalism, the difficulties to have a new } \\
\text { class of entrepreneurs emerge: «Hence, } \\
\text { with an emerging mass character of } \\
\text { economic life that was accompanied by a } \\
\text { 'democratisation' of the innovation } \\
\text { process, the leadership function of } \\
\text { entrepreneurship would become obsolete } \\
\text { (Schumpeter 1942, p. 132n).» (Backraus, } \\
\text { 2003: 135). }\end{array}$ & $\begin{array}{l}\text { Authoritarian Corporatism: «In Schumpeter's view, } \\
\text { guaranteeing elite "freedom of action" entailed restrictions } \\
\text { on the expression of most individuals, such as banning } \\
\text { citizens from engaging in "bombarding [their } \\
\text { representatives] with letters and telegrams" (1942: 295). In } \\
\text { another example of Schumpeter's lack of commitment to } \\
\text { free expression as a component of democracy, his vision of } \\
\text { the workplace in a "democratic" socialist society included } \\
\text { "dictatorship" over workers and the use of factory discipline } \\
\text { to curb workers' political expression (1942: 302).» in } \\
\text { Medearis, 2001: 125Since the legitimacy for the elite is its } \\
\text { superior talent, Schumpeter urges for more competition } \\
\text { among the talents: «(..) the roots of Schumpeter's famous } \\
\text { elite conception of democracy as a political method- } \\
\text { developed in Capitalism, Socialism, and Democracy } \\
\text { (1942)- (...) had three chief features: a focus on elite } \\
\text { competition for mass support, the treatment of democracy as } \\
\text { nothing more than an institutional arrangement, and the } \\
\text { attempt to decouple democracy from values such as equality } \\
\text { and participation. Schumpeter's conception of Tory } \\
\text { democracy-although formulated and expressed quite } \\
\text { differently-embodied each of these characteristics. His } \\
\text { argument focused on aristocratic domination of democratic } \\
\text { institutions.» (Medearis, 2001: } 35 \text { ). }\end{array}$ \\
\hline
\end{tabular}

Table 3. Key Issues and Solutions in Schumpeter's Capitalist System 


\begin{tabular}{|c|c|c|}
\hline & Oberkampf Toiles de Jouy & Knoll Inc. \\
\hline Monographs & $\begin{array}{l}\text { Chassagne }(1981 ; 1980) \\
\text { Chassagne, Dewerpe and } \\
\text { Gaulupeau (1976) } \\
\text { Dewerpe and Gaulupeau (1990) } \\
\text { Gril-Mariotte }(2015 ; 2009)\end{array}$ & $\begin{array}{l}\text { Hostra (2008) } \\
\text { Larrabee and Vignelli (1990) } \\
\text { Lutz (2010) } \\
\text { Staniszewski (1998) } \\
\text { Vignelli (1981) }\end{array}$ \\
\hline $\begin{array}{l}\text { Economic history (textile and } \\
\text { furniture in global trades in } \\
\text { different periods of time) }\end{array}$ & $\begin{array}{l}\text { Braudel (1992) } \\
\text { Chapman and Chassagne (1981) } \\
\text { Subrahmanyan (1990) } \\
\text { McCraw (1997) } \\
\text { Rousseau (1762) } \\
\text { Smith (1776) } \\
\text { Strauss (1947) } \\
\text { Strauss and Cropsey (2012) }\end{array}$ & $\begin{array}{l}\text { Ades (1995) } \\
\text { Campbell (1978) } \\
\text { Castillo (2010; 2005) } \\
\text { Floré (2012) } \\
\text { Floré and McAtte, 2017) } \\
\text { Genter (2010) } \\
\text { Harris (1995) } \\
\text { James (2006) } \\
\text { Kentgens -Craig (1999) } \\
\text { McAtee (2017) } \\
\text { Scranton (1997) } \\
\text { Speller (2014) } \\
\text { Tigerman (2007) }\end{array}$ \\
\hline $\begin{array}{ll}\begin{array}{l}\text { Historiography } \\
\text { doctrines and ideas) }\end{array} & \text { (economic } \\
\end{array}$ & \multicolumn{2}{|c|}{$\begin{array}{l}\text { Schumpeter (2006); Marx (1965 (1867)); Croce (2017 (1913)); Dockès } \\
\text { (2015); Dockès and Rosier (1991) }\end{array}$} \\
\hline $\begin{array}{l}\text { Archival Data (microfilms, online } \\
\text { documents via the French National } \\
\text { Archives (Gallica) and the U.S. } \\
\text { Library of Congress }\end{array}$ & $\begin{array}{l}\text {-Lettres patentes sur arrêt du } \\
\text { conseil du } 20 \text { mai 1783, en faveur } \\
\text { des sieurs Oberkampf et Sarrasin } \\
\text { de Maraise, entrepreneurs- } \\
\text { propriétaires de la Manufacture } \\
\text { Royale de Toile, AN MFICHE F- } \\
23630 \text { (426), L 1.15-MF2-4998 } \\
\text {-Pétition à l'Assemblée nationale } \\
\text { par les fabricans de toiles peintes } \\
\text { du royaume contre le projet de } \\
\text { décret qui adopte la convention } \\
\text { faite par le roi, avec la } \\
\text { république de Mulhausen, le } 22 \\
\text { septembre 1791 ([Reprod.])/ } \\
\text { Oberkampf } \\
\quad \text { ark:/12148/bpt6k437907 } \\
\text {-WIDMER Gottlieb, Mémorial de } \\
\text { la manufacture de Jouy, Copie } \\
\text { conservée à la bibliothèque du } \\
\text { musée de la Toile de Jouy, Jouy- } \\
\text { en-Josas }\end{array}$ & $\begin{array}{l}\text {-Knoll France Case (Archives } \\
\text { HEC-de l'auteur, B. Ramanantsoa) } \\
\text {-Annual Report pursuant to section } \\
13 \text { or } 15 \text { (d) of the Securities } \\
\text { Exchange Act of 1934, US } \\
\text { Security and Exchange } \\
\text { Commission; 10-K 1 knl- } \\
\text { 20131231x10k.htm 10-K } \\
\text {-Archives from Vogue and the } \\
\text { New York Times }\end{array}$ \\
\hline Visits & $\begin{array}{l}\text { Oberkampf-Toiles de Jouy } \\
\text { Museum (Jouy-en-Josas, } \\
\text { Yvelines) }\end{array}$ & $\begin{array}{l}\text { Knoll Museum (East Greenville, } \\
\text { Pennsylvania) } \\
\text { Shows in the "Cité de } \\
\text { l'architecture" (Paris) }\end{array}$ \\
\hline
\end{tabular}

Table 4. Data Triangulated in the Case-Studies 


\begin{tabular}{|c|c|c|}
\hline & Oberkampf & Knoll \\
\hline Their Trade & $\begin{array}{l}\text { Calico techniques of printing on cloth for dress } \\
\text { and interior design alike (furniture and setting) in } \\
\text { the early age of the manufacture as corporations } \\
\text { regulate arts and crafts. The «toiles de Jouy » are } \\
\text { famous for their prints of natural sceneries and } \\
\text { they are associated with the "French taste". } \\
\text { Textile involves a combination of skills, namely } \\
\text { the mastery of different techniques such as } \\
\text { spinning, printing and colours, which used to be } \\
\text { traditional skills for centuries and now related to } \\
\text { sciences and techniques such as biology, } \\
\text { chemistry and physics (Gril-Mariotte, 2015). }\end{array}$ & $\begin{array}{l}\text { Design is a combination: Ruskin, in } \\
1854 \text {, used the word in his writing } \\
\text { as "Design, properly so called, is } \\
\text { human invention, consulting human } \\
\text { capacity" with the meaning of the } \\
\text { art of picturesque delineation and } \\
\text { construction; original work in a } \\
\text { graphic or plastic art" (2002). } \\
\text { Interior design appears to be a } \\
\text { combination of architecture, } \\
\text { furniture in relation to specific uses } \\
\text { of space. }\end{array}$ \\
\hline Their Style & $\begin{array}{l}\text { The French "Beaux-Arts" tradition is called } \\
\text { "eclectic". } \\
\text { This style consists in combinations since "les arts } \\
\text { décoratifs" (Aussel and Berjouet, 2009) obey } \\
\text { conjointly to three types of laws and finds a } \\
\text { compromise between the artistic disciplines that } \\
\text { regulate them: that of the structure of construction } \\
\text { (architecture), that of composition ("beaux- } \\
\text { arts"/visual arts) and that of practical use } \\
\text { ("artisanat"/crafts). }\end{array}$ & $\begin{array}{l}\text { Modernist and functional design is } \\
\text { often referred to the Bauhaus school } \\
\text { of design. Knoll is identified as "the } \\
\text { international modern", a mix of } \\
\text { multiple cultural traditions } \\
\text { (European, American, Asian) as } \\
\text { visible in the colours and the } \\
\text { patterns broadening the traditional } \\
\text { functional and minimal range of } \\
\text { "modern style". }\end{array}$ \\
\hline $\begin{array}{l}\text { Their Age } \\
\text { (Zeitgeist/"period's } \\
\text { eye" for } \\
\text { representations }\end{array}$ & $\begin{array}{l}1770-1820 \text { (from the beginning of the venture to } \\
\text { the death of the founder, Christophe-Philippe } \\
\text { Oberkampf. The family business goes bankrupt in } \\
1847 /\end{array}$ & $\begin{array}{l}\text { 1940-1970 (from the beginning of } \\
\text { the venture by Hans Knoll to the } \\
\text { retirement of Florence Knoll). } \\
\text { Knoll Inc. still exists, Florence } \\
\text { Knoll quit the head of the firm in } \\
\text { 1970. The net sales for } 2017 \\
\text { amounted to } 1.133 \text { million dollars. }\end{array}$ \\
\hline
\end{tabular}

Table 5. Comparison of two entrepreneurs and their trade, style, and age 